\title{
The Role of Sectoral Growth Patterns in Labor Market Development
}

\begin{abstract}
:
This paper investigates the relationship between sectoral growth patterns and employment outcomes. A broad cross-country analysis reveals that in middle-income countries, employment responds more to growth in less productive and more labor-intensive sectors. Employment in middle-income countries is susceptible to a resource curse, and grows rapidly in response to manufacturing and export manufacturing growth. Within Brazil, Indonesia, and Mexico, the effects of different sectoral growth patterns are context dependent, but differences in sectoral growth effects on employment and wages are substantially reduced in states or provinces with higher measured labor mobility. Consistent with this, aggregate employment and wage effects of growth by sector are close to uniform when examined over longer time horizons, after labor has an opportunity to adjust across sectors. The results reinforce the importance of growth in more labor-intensive sectors, and suggest that job mobility may be an important mechanism to diffuse the benefits of capital-intensive growth.
\end{abstract}

Francisco Javier Arias-Vazquez

Jean N. Lee

David Newhouse*

World Bank, Social Protection and Labor, 1818 H Street, Washington DC, 20433.

*Corresponding author: Email: dnewhouse@worldbank.org

JEL codes: 011, J20

Keywords: Economic Growth, Production Structure, Employment, Unemployment, Productivity 


\section{Introduction}

Developing countries are typically characterized by large and persistent productivity and earnings differences across sectors, with large numbers of workers toiling in low-productivity jobs in agriculture or small-scale trading. The reallocation of these workers into more productive employment plays a critical role in increasing productivity, promoting living standards, and ultimately lifting people out of poverty. This is consistent with the longstanding view that long-term improvement in incomes and reductions in income inequality require a structural transformation out of agriculture into more productive sectors, where wages are higher (Lewis, 1954; Chenery and Syrquin, 1975; Foster and Rosenzweig, 2007).

Because the reallocation of workers to more productive sectors is necessary for development, both researchers and policymakers are often keenly interested in the implications of different patterns of sectoral growth. Most discussion, based on the East Asian experience, focuses on the importance of export-oriented manufacturing growth as an engine of employment and productivity growth (Balassa, 1978; Amiti and Freund, 2010). This focus is at least partially consistent with a recent study, based on 55 countries, which finds that growth in agriculture, construction, and notably manufacturing lead to the most rapid poverty reduction (Loayza and Raddatz, 2010). In this case, growth in sectors where the poor can easily be employed appears to benefit them most.

Other studies, however, have emphasized the implications of growth in other economic sectors, such as natural resources (Sachs and Warner, 1995; Sachs and Warner, 1999; Robinson et al, 2006). McMillan and Rodrik (2012), for example, consider 38 countries, 25 of which are low or middle-income, and find evidence for a "natural resource curse" reflected in employment patterns in these countries. Countries with a higher share of exports in natural resources were more likely to experience growth-reducing changes in labor allocation across sectors, because the high productivity resource sector was unable to absorb large amounts of labor. This is consistent with the results from two natural experiments, one following an increase in demand for coca paste in rural Columbia and the other following the discovery of oil fields in Brazil, that also suggest that natural resource booms lead to disappointing employment and growth outcomes. ${ }^{1}$ Another study finds evidence for important increases in civil conflict in oil producing regions of Colombia as oil prices rise, and further relates the ramifications of commodity price shocks for political stability to the labor intensity and employment effects of increased production, studying price shocks to oil, coal, gold, coffee, bananas, sugar, palm and tobacco (Dube and Vargas, forthcoming). Nonetheless, a recent thorough review highlights the paucity of evidence from panel-data and quasi-experimental studies on the economic effects of the resource curse. ${ }^{2}$

Yet another strand of the literature has stressed the role of agricultural growth in promoting structural change and reducing poverty (Sadoulet and de Janvry, 2010; Christiaenson et al, 2011). One study, for example, reports the results of model simulations in which growth in agricultural productivity hastens industrialization and is therefore central to development. ${ }^{3}$ A subsequent study, however, suggests that agricultural growth may be less important than non-agricultural growth in low-income settings, and others emphasize the importance of the growth of nonfarm industries for poverty reduction even in rural areas. ${ }^{4}$ Empirical evidence from China, India, and Indonesia indicates that agricultural growth has strong effects on poverty reduction in some contexts (Ravallion and Chen, 2007; Ravallion and Datt, 1996; Suryahadi et al, 2010).

\footnotetext{
${ }^{1}$ Angrist and Kugler (2008), and Caselli and Michaels (2009).

${ }^{2}$ Van Der Ploeg (2011), Haggblade et al (2002), Headey et al (2010), and Lanjouw and Lanjouw (2001). See also Ferreira et al (2010) for evidence on service sector growth and poverty reduction in Brazil.

${ }^{3}$ Gollin, et al (2002).

${ }^{4}$ Alvarez-Cuadrado and Poschke (2011).
} 
In short, the published evidence on sectoral growth and poverty generally agrees that growth in labor-intensive sectors such as manufacturing, construction, and agriculture may most benefit the poor, while natural resource growth fails to spur productivity increases for the majority of workers. However, this evidence varies considerably in different contexts and is far from definitive, and the literature demonstrates no clear consensus on the role of sectoral growth patterns in improving labor market outcomes and thus reducing poverty. The lack of clear evidence on the link between growth and employment patterns is surprising, given the strong interlinkage between employment status and poverty. ${ }^{5}$ Policymakers' perceptions regarding sectoral growth patterns and employment can have important implications for growth strategies as well as policies towards trade, exchange rates, and industrial development.

This paper brings new evidence to bear on how changes in labor market outcomes, such as employment rates, unemployment rates, wages, and wage and non-agricultural employment, productivity, vary with sectoral growth patterns. We focus on whether growth in low productivity sectors or higher-productivity sectors generates greater growth in wages and employment. While broad labor market indicators such as employment are of interest in their own right, more specific indicators such as wages, productivity, and types of employment are closely related to poverty and economic development, but unfortunately less frequently observed or analyzed. This analysis takes advantage of the wealth of labor market data available in the World Bank's International Income Distribution Database (I2D2) and in several country-specific labor market surveys to include these more specific indicators in our empirical exploration of the employment consequences of sector-specific growth. ${ }^{6}$

We begin with a cross-country analysis in which these data are combined with UN country-level data on growth in seven sectors to estimate the impact of growth in different sectors on employment growth, wage growth and productivity growth. The resulting database of growth patterns and labor market outcomes includes 184 surveys in 81 countries.

The cross-country analysis is supplemented with three country case studies from Brazil, Indonesia and Mexico. These case studies utilize annual and retrospective data from labor force and household surveys, and use stateand province-level variation in sectoral growth rates to identify the relationship between sectoral growth rates and labor market outcomes. A unique feature of these three countries is the availability of panel data on workers, which allows us to examine how the effect of different sectoral growth patterns is mediated by workers' mobility across jobs.

When looking across countries at the short-run effects of sectoral growth, growth in less productive sectors, compared to more productive sectors, increases employment and reduces unemployment. Growth in mining and utilities, in contrast, is associated with increased unemployment and reduced employment, providing some empirical support to the notion of a "resource curse" in employment outcomes. Meanwhile, manufacturing growth is associated with a substantial increase in employment and decline in unemployment among middleincome countries. Sectoral growth has surprisingly few noticeable impacts on other job characteristics that are important indicators of economic development, such as earnings, sectoral productivity, and the structural transformation out of agriculture and into wage employment. The analysis, however, lacks sufficient statistical power to rule out potentially large effects of sectoral growth patterns on these indicators.

The within-country analyses of recent growth patterns in Brazil, Indonesia and Mexico do not conform to this or any other consistent pattern. In Brazil, employment outcomes are comparable for high and low productivity sector growth. In Indonesia, in contrast, high productivity sector growth reduces employment effects and increases

\footnotetext{
${ }^{5}$ See Gutierrez et al (2007).

${ }^{6}$ For more information on an earlier version of the 12D2 database, see Montenegro and Hirn (2009).
} 
wage growth. In Mexico, growth high productivity sectors are associated with stronger employment growth, but, if anything, slower growth in wages and labor productivity.

At the one digit level, employment rises with manufacturing growth in Brazil and Mexico, which is in line with the cross-country finding that manufacturing growth increases employment in middle-income countries. The Indonesian data also show some evidence of a type of "resource curse", as mining growth is associated with statistically significantly slower employment and wage growth. In general, however, growth patterns at the 1-digit sector level fail to show a consistent pattern across the three countries. Employment is boosted more by agriculture growth in Indonesia and financial sector growth in Mexico. Meanwhile, wage increases are associated with growth in manufacturing in Indonesia, but growth in the public and financial sectors and in Mexico.

In analyses of growth over longer periods using census data from these countries, we find little evidence for differential employment or wage effects of growth across sectors over longer horizons, when technologies and labor markets have an opportunity to adjust, with strikingly similar point estimates on agriculture, industry and services growth. Consistent with this differential between short- and long-run effects, we find that higher measured labor mobility strongly attenuates the differences between the growth effects of high and low productivity sectors in all three countries in our shorter-run analyses. ${ }^{7}$

Overall, the results confirm some commonly held preconceptions, while challenging others. In middle income countries, less productive sectors are more effective in increasing employment, manufacturing growth increases employment and reduces unemployment, and natural resource growth does the opposite. However, there is a notable lack of evidence that growth patterns affect wages, wage employment, non-agricultural employment, and productivity, although most of these estimated effects are admittedly imprecise and cannot rule out large effects. Agricultural growth also has surprisingly minor effects on aggregate labor market outcomes, even in low-income countries. Finally, the differential effects of sectoral growth are likely to be more significant over the shorter run, when labor is relatively immobile. The results suggest that it may be appropriate for longer run employment generation and poverty reduction strategies to maximize overall growth, rather than prioritizing growth in specific sectors.

In the next section we describe the data and provide summary statistics and background information about the Brazilian, Indonesian and Mexican economies and labor market structures. Section 3 describes the empirical methods. In section 4, we examine labor market outcomes and how they respond to year-on-year shocks to sectoral growth rates, in both the cross-section and the three countries. In section 4, we also discuss sectors that often receive special attention in both the literature and popular discussion, such as agriculture, export manufacturing, and mining and natural resource extraction. In section 5 , we focus exclusively on the three case studies and examine the role of labor mobility and longer-term estimates of sectoral growth impacts. Section 6 concludes.

\section{Data and Background}

\footnotetext{
${ }^{7}$ Our result supports the notion that as in Topalova (2008), differential labor market mobility may affect the distributional implications of growth patterns.
} 
To relate sectoral growth patterns to labor market outcomes, we first obtained information on GDP by sector at the national level from the United Nations. The UN GDP data are disaggregated according to the following sectors: agriculture, hunting, forestry, and fishing (ISIC A-B); mining, manufacturing and utilities (ISIC C-E), manufacturing (ISIC D); construction (ISIC F); wholesale, retail trade, restaurants and hotels (ISIC G-H); transport, storage and communication (ISIC I); and other activities (ISIC J-P). ${ }^{8}$ We also use information on GDP by sector and state or province from Mexico, Indonesia, and Brazil. These cover most of the following sectors in each country: agriculture, mining, construction, electricity, manufacturing, retail trade, transport and communication, finance and business services, social services, other services and the public sector. Data on manufacturing exports come from the World Bank's World Development Indicators database, and data on labor regulation from the World Bank's Doing Business indicators database.

For information on labor market outcomes at the country level, we turn to the standardized survey data included in the World Bank's International Income Distribution Database (I2D2). For the within-country analyses of annual growth and changes in employment outcomes, we primarily use data from Brazil's Monthly Employment Survey (PME) from 2003 to 2009; the 1997, 2000, and 2007 waves of the Indonesia Family Life Survey (IFLS); and the Mexican National Survey of Occupation and Employment (ENOE) from 2005 to 2010 to measure changes in labor market outcomes. Brazil's Monthly Employment Survey (PME) is a rotating panel survey, but it only covers major urban areas in six states of Brazil, making it the most limited in scope of the country-level data sources we use. We therefore supplement the PME with information from 2003 to 2009 from the Pesquisa Nacional por Amostra de Domicilios (PNAD), which is conducted annually and broader in geographical coverage, but is not a panel survey. ${ }^{9}$ Unlike in Brazil, the Mexican labor force survey (ENOE) is representative of all 32 states, includes a quarterly rotating panel of survey respondents, and is a rotating panel. We use the first and last interview quarters for each individual to capture annual changes in employment status. Finally, the Indonesian estimates are obtained from the Indonesia Family Life Survey (IFLS), which sampled households from 13 provinces representing 83 percent of the population in its initial round in 1993. Unlike the Brazillian and Mexican data, the IFLS is not a rotating panel and more than 90 percent of the original households were successfully re-contacted in 1997, 2000, and 2007. The survey also tracks movers, and obtains a complete retrospective labor market history spanning from 1988 to 2007. ${ }^{10}$ For some outcomes, specifically to distinguish between unemployment and nonparticipation in the labor force, we supplement this with information from the National Labour Force Survey for Indonesia (SAKERNAS).

While these household surveys are valuable, largely because they are longitudinal, they do not allow us to examine how sectoral growth patterns relate to labor market changes in the long run. We therefore supplement the analysis using public use census microdata samples for Brazil in 1960, 1970, 1980, 1990 and 2000; for Indonesia in 1971, 1980, 1990, 2000 and 2010; and for Mexico in 1990, 2000 and 2010. In these longer-run analyses, we are constrained by the availability of sectoral GDP data at the sub-national level to analyze the three broad sectors of agriculture, services and industry. Workers are matched to state- or province-specific data on sectoral gross domestic product (GDP) from national statistical offices, based on their state or province of residence.

Using each of these outcome datasets, we construct five main measures of workers' labor market outcomes: Whether they are employed, unemployed, or out of the labor force, their log wage, and the sector's log productivity (value added per worker) in the sector of employment. For the cross-country analysis, this is also supplemented with an analysis of wage employment and non-agricultural employment.

\footnotetext{
${ }^{8}$ For the purposes of our analysis, we separate mining and utilities (ISIC C and E) from manufacturing (ISIC D).

${ }^{9}$ We use aggregates at the state and sector level to generate estimates of average wage and productivity growth from the PNAD.

${ }^{10}$ Note that wage data are only available through 2000.
} 
Based on average labor productivity estimates from these data, industries are characterized as being "high productivity" if they fall in the following set: manufacturing, transport and communications, finance, electricity and utilities, or mining. We group the following industries into the "low productivity" set: other services, agriculture, retail and wholesale trade, government and public administration, and construction. This classification was based on the ranking of sectors according to their productivity.

The annual panel data cover periods in Indonesia and Mexico including two recent major recessions: the Indonesian financial crisis of 1997-1998, and the more recent recession in Mexico following the global financial crisis, beginning in 2008-2009. During both of these recessions, industrial growth was hit the hardest: industrial growth declines disproportionately in Indonesia in 1997 and never recovered to pre-crisis levels, and declines more than agricultural and service sector growth in Mexico during the more recent recession there

Labor market mobility, as evidenced by transitions across sectors and transitions out of unemployment, is very high in Mexico, with roughly one in six workers moving sectors in any given year. Labor market transitions reported in the Indonesian data are markedly less frequent, occurring for up to 9 percent of workers in any given sector, although changes in industry may be underreported in these retrospective data. Labor market transitions are also very common in Brazil's PME, with approximately 1 in 5 workers moving sectors within a year, although this number only reflects the rate of transitions for urban workers. Mexico and Brazil's higher labor market mobility relative to Indonesia, if not an artifact of the nature of the data, may perhaps be related to their much more diverse economic structures. Indonesia's economy in 2007 was more heavily agricultural than that of the other two countries, with 33 percent of workers employed in agriculture, one of the sectors with the lowest labor productivity, relative to Mexico's 13.5 percent share.

\section{Empirical Methods}

In our cross-country analysis, countries are observed in different years and at disparate intervals, and we therefore follow Loayza and Raddatz (2010) in calculating annualized growth rates in employment outcomes and in sectorspecific GDP over these intervals. We also weight sectoral growth by GDP share. Besides adjusting for the size of different sectors in the economy, this allows for tests of the equality of coefficients across sectors, as in Loayza and Raddatz (2010) and Ravallion and Chen (2007). As noted in those papers, the case in which the coefficients on different share-weighted sectors are statistically indistinguishable corresponds to the case that only overall growth matters and the sectoral composition of growth does not.

We regress these annualized changes in employment outcomes on share weighted GDP by sector:

$$
\hat{e}_{c, t}=\beta_{0}+\sum_{k=1}^{7} \beta_{k} S_{c, k, t} \hat{y}_{c, k, t}+\varepsilon_{c, t}
$$

where $\hat{e}_{c, t}$ is the annualized change of an employment outcome in country c at period t, $s_{c, k, t}$ is the GDP share of sector $\mathrm{k}$ in country $\mathrm{c}$ at period $\mathrm{t}$, and $\hat{y}_{c, k, t}$ is the growth rate of output in sector $\mathrm{k}$ in country $\mathrm{c}$ at period $\mathrm{t}$. We test for significant effects of growth composition on employment outcomes by testing equality of $\beta_{1}$ through $\beta_{7}$.

Unlike Loayza and Raddatz (2010), we are initially interested in the effects of shorter-run growth on employment outcomes, to keep estimates comparable to those using annual growth and individual-level panel data for Brazil, 
Indonesia and Mexico. Therefore, the analysis uses every interval in which growth and changes in employment outcomes are observed to estimate the relationship between sectoral growth patterns and employment outcomes. Because there are multiple observations per country, we cluster standard errors at the country level.

We then restrict the coefficients to be equal among high and among low productivity sectors, and estimate the following variant of equation (1):

$$
\hat{e}_{c, t}=\beta_{0}+\beta_{H i g h}\left(\sum_{H i g h} s_{c, k, t} \hat{y}_{c, k, t}\right)+\beta_{L o w}\left(\sum_{L o w} s_{c, k, t} \hat{y}_{c, k, t}\right)+\varepsilon_{c, t} .
$$

To test for differences in effects of growth of high and low productivity sectors, we test for equality of $\beta_{\text {High }}$ and $\beta_{\text {Low }}$.

Export-led manufacturing growth may have distinctive effects on labor markets. To test for this, in the crosscountry data, we simply regress growth in employment outcomes on total GDP growth and growth in export manufacturing, denoted $\hat{x}$ :

$$
\hat{e}_{c, t}=\beta_{0}+\hat{y}_{c, t}+\hat{x}+\varepsilon_{c, t}
$$

The specifications for the country-specific analysis using panel data for Brazil, Indonesia, and Mexico are similar in spirit to the cross-country analysis. Where possible, the specifications include individual-level fixed effects to empirically assess the relationship between sectoral growth patterns and changes in employment status. Individual fixed effects, rather than state or province-level dummies, are included to improve efficiency, as they affect consistency only in the Indonesian case. ${ }^{11}$ We estimate the following specification:

$$
e_{i, r, t}=\beta_{0}+\sum_{k=1}^{10} \beta_{k} s_{r, k, t} y_{r, k, t}+\theta_{i}+\delta_{t}+\varepsilon_{i, r, t}
$$

Where $e_{i, r, t}$ is employment outcome for person $\mathrm{i}$ in region (state or province) $\mathrm{r}$ at time $\mathrm{t}, s_{r, k, t}$ is the GDP share of sector $\mathrm{k}$ in region $\mathrm{r}$ at time $\mathrm{t}$, and $y_{r, k, t}$ is output in sector $\mathrm{k}$ in region $\mathrm{r}$ at time $\mathrm{t}$, and $\theta_{i}$ is an individual fixed effect. In practice, as we have an initial and final observation for each individual in the panel data, we estimate this equation in first differences:

$$
\Delta e_{i, r, t}=\sum_{k=1}^{10} \beta_{k} s_{r, k, t} \Delta y_{r, k, t}+\tilde{\delta}_{t}+\widetilde{\varepsilon}_{i, r, t}
$$

Then, as with the cross-country data, we restrict coefficients to be equal among high productivity sectors and among low productivity sectors, and test for differences in effects of high and low productivity sector growth ${ }^{12}$ :

\footnotetext{
${ }^{11}$ This is because only the Indonesian data tracks interprovincial migrants.

${ }^{12}$ For the specifications described above, we also test for robustness to the inclusion of country-, state- or province-specific trends.
} 


$$
\Delta e_{i, r, t}=\beta_{H i g h}\left(\sum_{H i g h} s_{r, k, t} \Delta y_{r, k, t}\right)+\beta_{\text {Low }}\left(\sum_{\text {Low }} s_{r, k, t} \Delta y_{r, k, t}\right)+\tilde{d}_{t}+\widetilde{\varepsilon}_{i, r, t}
$$

The impact of sectoral growth patterns may depend on worker mobility between jobs. To assess this, we construct state- or province-level measures of labor mobility in Brazil, Indonesia, and Mexico, using the individual-level panel data on industry of employment. Our primary measure is the average share of individuals in a state who change industries within one year. We also use the occupational information to construct an alternative measure of labor mobility: the share of individuals in a state who change occupations within a year. The results are largely robust to use of this alternative measure.

$$
\begin{aligned}
\Delta e_{i, r, t}= & \beta_{\text {High }}\left(\sum_{H i g h} s_{r, k, t} \Delta y_{r, k, t}\right)+\beta_{\text {Low }}\left(\sum_{\text {Low }} s_{r, k, t} \Delta y_{r, k, t}\right)+ \\
& \beta_{\text {HighLM }}\left(\sum_{H i g h} s_{r, k, t} \Delta y_{r, k, t}\right) * L M+\beta_{\text {LowLM }}\left(\sum_{\text {Low }} s_{r, k, t} \Delta y_{r, k, t}\right) * L M_{r}+\widetilde{\delta}_{t}+\widetilde{\varepsilon}_{i, r, t}
\end{aligned}
$$

For each country, to test whether the differential between the effects of high and low productivity growth changes with flexibility in the labor market, we regress changes in labor market outcomes on the share weighted growth rates of high and low productivity sectors, interacted with these labor mobility measures:

where $L M_{r}$ is the measure of average labor mobility at the state or province level.

We attempt to conduct an analogous test in the cross-country data. Because empirical information on labor market transitions are not available for a broad set of countries, we use measures of labor regulation from the Doing Business database, despite the inconclusive evidence on the link between labor regulations and job mobility. ${ }^{13}$

$$
\begin{aligned}
\hat{e}_{c, t}= & \beta_{0}+\beta_{\text {High }}\left(\sum_{H i g h} s_{c, k, t} \hat{y}_{c, k, t}\right)+\beta_{L o w}\left(\sum_{L o w} s_{c, k, t} \hat{y}_{c, k, t}\right)+ \\
& \beta_{\text {HighLR }}\left(\sum_{H i g h} s_{c, k, t} \hat{y}_{c, k, t}\right) * L R_{c}+\beta_{\text {LowLR }}\left(\sum_{L o w} s_{c, k, t} \hat{y}_{c, k, t}\right) * L R_{c}+\varepsilon_{c, t}
\end{aligned}
$$

Finally, we turn to census data for Brazil, Indonesia and Mexico to assess the longer run effects of sectoral growth patterns on employment outcomes. We estimate:

\footnotetext{
${ }^{13}$ For example, Kugler (2004) and Saavedra and Torrero (2004) found that loosening employment protection legislation led to a moderate increase in job separations and hiring in Colombia and Peru, but Paes de Barros and Corseuil (2004) and Petrin and Sivadasan (2006) find little evidence that increased regulations decreased mobility in Brazil or Chile.
} 


$$
e_{i, r, t}=\beta_{0}+\sum_{k=1}^{3} \beta_{k} s_{r, k, t} y_{r, k, t}+\gamma_{r}+\delta_{t}+\varepsilon_{i, r, t}
$$

where $\gamma_{r}$ are state or province fixed effects and $\delta_{t}$ are year effects and sectors include agriculture, services and industry.

\section{Sectoral growth impacts on employment}

\subsection{High and low productivity sector growth}

Is growth in high or low-productivity sectors more strongly associated with employment creation? Before addressing this question, we first put changes in employment and unemployment into context by comparing how they evolve with per capita GDP. Figure 1a shows a smoothed average of countries' employment to population ratio at different levels of per capita GDP. For low-income countries, employment falls rapidly as per capita GDP increases, as a larger share of the population can afford to exit the labor force. This fall is dramatic, from about two thirds of the population for the poorest countries, to a low of about half for lower middle-income countries, at about $\$ 2000$ per capita. Employment then gradually rises, to about 60 percent for the richest countries. Figure $1 \mathrm{~b}$ tells a similar story in reverse. Average unemployment rates start at about 12 percent and rise to just over 15 percent, as more workers can afford to search, before falling again to 15 percent. These figures illustrate two key points. First, for low-income countries, employment declines and unemployment increases may arguably be a welcome sign of economic growth and development. Secondly, even a relatively small employment increase or unemployment decline, on the order of one half to one percentage point, constitutes an important employment improvement in middle and high-income countries.

Although the interpretation of employment changes depends heavily on the country's level of development, we begin first by presenting aggregate results in Table 2. These are taken from Equation (2), which estimates how annualized growth rates of employment relate to share-weighted sectoral growth rates. They show moderate differences in the effects of high and low productivity sector growth on employment and unemployment. In a sample of 81 countries with matched growth and employment outcome data, low productivity growth appears to be associated with significantly faster growth in employment and reductions in unemployment relative to high productivity growth. However, if anything, high productivity growth may be associated with faster wage and labor productivity growth, although the differences are not statistically significant.

In terms of magnitudes, a one percentage point increase in overall GDP due to high-productivity sectors raises employment, as a share of the population, by 0.2 percentage points (significant at the 5 percent level), while low productivity growth is associated with an increase of 0.08 percentage points (not statistically different from zero), and the difference $\left(\beta_{\text {Low }}-\beta_{\text {High }}=0.295\right)$ is marginally statistically significant at the 10 percent level (test $p$-value $=0.075$ ). This suggests that on average, low productivity growth leads to faster employment growth than does high productivity growth. Similarly, low productivity sector growth appears to be associated with faster declines in unemployment. High productivity growth is associated with a coefficient of 0.067 , meaning that a one percentage 
point increase in GDP growth due to the productive sectors is associated with a roughly 0.07 percentage point increase in the unemployment rate. Meanwhile, a comparable increase in the growth of low-productivity sectors is associated with a reduction of 0.16 percentage points (significant at the 1 percent level). The difference $\left(\beta_{\text {Low }}-\beta_{\text {High }}=-0.229\right)$ is significant at the 5 percent level (test $p$-value $\left.=0.021\right)$. With respect to inactivity, growth in more productive sectors may marginally raise the share of population that is out of the labor force, with a point estimate of 0.149 , but the difference in coefficients for high and low productivity growth is not significant $\left(\beta_{\text {Low }}-\beta_{\text {High }}=-0.067\right)$. In contrast to these results on employment growth, it appears that if anything, high productivity sector growth may lead to faster wage and labor productivity growth relative to low productivity sector growth, although the coefficients are imprecisely estimated and the differences between coefficients are not statistically significant. ${ }^{14}$

As noted above, the interpretation of employment and unemployment changes depend on countries' stage of development, as declines in employment and increases in unemployment often reflect economic growth in lowincome countries. Figures 2, 3 and 4 show how the estimated effects of growth in high and low productivity sectors vary according to countries' per capita GDP. For low-income countries, high-productivity sectors are associated with a slightly greater reduction in employment, but differences with less productive sectors is not statistically significant, as the top dashed blue line in figure 2 exceeds the lower dashed red line. The bigger story, however, is the positive effect of low-productivity growth on employment for middle-income countries, particularly those in the $\$ 2000$ to $\$ 10,000$ range. Here, a 1 percent increase in aggregate growth due to more productive sectors is associated with an increase in employment of half a percentage point, while growth in more productive sectors is associated with a slight decline. The unemployment results also show a beneficial effect of less productive sectors in middle-income countries. For low income countries, growth in more productive sectors is associated with a slightly greater increase in unemployment, but the differences with less productive sectors are relatively minor. Estimated impacts on unemployment start to diverge at just under $\$ 2000$ per capita, as growth in less productive sectors begins to have a substantial negative and statistically significant effect; at its peak, a one percentage point increase in growth due to less productive sectors lowers unemployment rates by half a percentage point. To sum up, employment and unemployment in middle-income countries responds favorably to growth in less productive, more labor-intensive, sectors.

Turning to our case study countries of Brazil, Indonesia and Mexico, we find that the effects of high and low productivity sector growth are not uniform across contexts, and may potentially differ based on institutional factors or structural features of the labor market. Within Brazil, unlike the cross-country analysis, the effects of high and low productivity sector growth on employment and unemployment are broadly similar. High productivity sector growth is associated with weakly positive effects on employment growth, while low productivity sector growth is associated with weakly negative effects on employment growth. The difference between coefficients, however, is not statistically significant (test $p$-value $=0.384$ ). A one percentage point increase in aggregate GDP due to high-productivity sectors is associated with a tiny 0.03 percentage point reduction in unemployment, though the estimate is precise (significant at the 1 percent level). Low productivity growth is associated with an even weaker 0.02 percentage point reduction in the unemployment rate, and the difference between high productivity and low productivity coefficients is not statistically distinguishable from zero (test $p$-value $=0.274$ ). High productivity growth and low productivity growth are also indistinguishable in their effects on growth or reductions in the share of the population that is out of the labor force (test $p$-value $=0.526$ ).

\footnotetext{
${ }^{14}$ In specifications allowing for country-specific growth rates, we similarly find point estimates that suggest that growth in lower productivity sectors differentially reduces unemployment. These estimates, however, suggest that this reduction in unemployment may largely come from increases in dropout from the labor force, and that growth in higher productivity sectors significantly increases non-agricultural employment relative to growth in lower productivity sectors.
} 
One caveat is that for these three outcomes in Brazil, we use data from the PME, which is only representative of urban workers in six states. We therefore supplement the PME with data from the PNAD, which is a nationally representative household survey, to estimate effects on the remaining two outcomes. In fact, using the PNAD makes little difference, as the results on high productivity and low productivity sector growth on log wages and log productivity are comparable to those from the PME. Both high productivity and low productivity sector growth are associated with modest increases in wage growth, although both point estimates are statistically indistinguishable from zero and from each other (test $p$-value $=0.256$ ). The estimates of the effects of high productivity and low productivity sector growth on productivity growth are also strikingly similar in Brazil, with high productivity growth associated with a point estimate of 0.277 (significant at the 1-percent level) and low productivity growth associated with a point estimate of 0.254 (also significant at the 1-percent level). Despite the increased precision due to the use of data from many more provinces, the point estimates are not statistically different from each other (test $p$-value $=0.250$ ).

Indonesia is more consistent with the results from the cross-country analysis, as high-productivity growth appears to be more effective at reducing employment than growth in less productive sectors. The coefficient on high productivity growth is larger in magnitude (-0.235) than the coefficient and low productivity growth. Thus, in Indonesia, a one percentage point increase in GDP growth due to more productive sectors is associated with a 0.2 percentage point decline in the employment to population ratio. The difference between coefficients is marginally significant (test $p$-value $=0.061$ ). Because Indonesia's per capita GDP was roughly $\$ 800$ in 2000 , it is possible that growth in more productive sectors proved more beneficial to workers by allowing more to voluntarily exit the labor force.

The wage results also appear to match both the cross-country analysis and are consistent with beneficial labor market effects from more productive sectors, with the caveat that most of the wage data is retrospective. Specifically, high productivity growth appears to raise wages more than low productivity growth in Indonesia. The coefficient on high productivity growth (1.790, significant at the 1-percent level) suggests that a one percent increase in aggregate GDP increases wages by 1.8 percent, and is much larger than and statistically distinguishable from the coefficient on low productivity growth $(0.022$, not statistically distinguishable from zero), with a test $p-$ value of 0.010 . However, the Indonesian results are heavily influenced by the events of the 1998 financial crisis, which led simultaneously to a steep decline in higher-productivity sectors and extraordinary real wage declines on the order of 40 percent. Looking at productivity growth, which is available for a wider set of years, tells a different story. Low productivity growth appears to raise labor productivity significantly more than does high productivity growth, with the difference between coefficients significant at the 5 percent level.

Turning to Mexico, estimates of the impacts of high and low productivity growth also suggest much larger effects of high productivity sector growth in that context. A 1 percent increase in growth due to high productivity sectors is associated with employment growth that is faster by 0.25 percent (coefficient significant at the 1 percent level), while a 1 percent increase in growth due to low productivity sectors is associated with employment growth that is faster by only 0.07 percent (not statistically different from zero). The difference between coefficients, however, is not statistically different from zero (test $p$-value $=0.135$ ). Unemployment rates also appear to drop more with high productivity sector growth $\left(\beta_{\text {High }}=-0.084\right.$, significant at the 1 percent level) than with low productivity sector growth ( $\beta_{\text {Low }}=-0.013$, not statistically distinguishable from zero). Results on the likelihood of being out of the labor force look very similar to those for unemployment, with growth in high productivity sectors leading to much larger declines in the likelihood of being out of the labor force $\left(\beta_{\text {High }}=-0.168\right.$, significant at the 1 percent level) than growth in low productivity sectors $\left(\beta_{\text {Low }}=0.051\right.$, not statistically distinguishable from zero), but again, the coefficients are not statistically different from each other (test $p$-value $=0.267$ ). 
In Mexico, the impacts of sectoral growth patterns on wage growth appear small, but as in Indonesia, low productivity sector growth appears to lead to more rapid increases in average labor productivity than does high productivity sector growth. Wage impacts of both high and low productivity sector growth are small and statistically insignificant, as well as indistinguishable from each other (test $p$-value $=0.733$ ). The impact of low productivity sector growth on labor productivity appears large and positive $\left(\beta_{\text {Low }}=1.040\right.$, significant at the 1 percent level). The impact of high productivity sector growth on labor productivity also appears positive, but smaller $\left(\beta_{\text {High }}=0.347\right.$, marginally significant at the 10 percent level). The difference in coefficients for productivity appears to be significant (test $p$-value $=0.021$ )

In sum, the cross-country evidence suggests that growth in low-productivity sectors do more to increase employment and reduce unemployment, especially in middle-income countries. The country case studies are less conclusive, however, and suggest caution before generalizing cross-country patterns to particular contexts. In none of the three cases did low-productivity sectors clearly have stronger employment or unemployment effects than more productive sectors.

\subsection{Growth disaggregated at the 1-digit sector level: agriculture, export-led manufacturing, and natural resources}

The differences in the results between low and high-sector growth, both across and within countries, suggest that growth in individual sectors may have distinctive effects. We therefore turn to estimating the effects of growth in more finely disaggregated sectors on employment outcomes.

In the cross-country data, we use data from the United Nations disaggregated primarily at the 1-digit sector level to create seven output categories (Table 4). In contrast to the literature emphasizing the special importance of agricultural growth or manufacturing, we find only evidence for strongly differentially negative effects of growth in mining and utilities on employment growth. ${ }^{15}$ Similarly, we find large and significant increases in the unemployment rate associated with mining and utilities growth in the cross-country analysis. ${ }^{16}$ Besides mining and utilities, there is little evidence of other sectors differentially affecting employment outcomes, except for the anomalous result that growth in "other" industries (largely services) has more positive effects on wage growth.

The previous section illustrated the importance of disaggregating the average effects presented in the crosscountry regressions, to consider how impacts on employment and unemployment depend on countries' level development. In low-income contexts, employment tends to declines with growth, and open unemployment is typically a poor indicator of labor market health. For this reason, we estimate impacts separately for each period using locally weighted regressions, based on countries' log GDP per capita in 2000, shown in Figures 5-7. ${ }^{17}$ Each dot represents a different period for which both changes in GDP by sector and labor market outcomes are observed.

\footnotetext{
${ }^{15}$ This result is somewhat sensitive to specification choice. We separately estimate effects of mining and utilities growth and manufacturing growth by subtracting manufacturing output from the groupings of ISIC C-E (mining, manufacturing and utilities) provided in the raw data from the United Nations. When using the raw data as provided, we find a large and strongly positive coefficient of manufacturing growth on employment growth, although the net effect, adding the coefficients on ISIC C-E and on ISIC-D, manufacturing alone, is much more weakly positive.

${ }^{16}$ This result is robust to the inclusion of country or province-specific trends in both the cross-country analysis and when looking at Indonesia, although in the latter case, in specifications including province-specific trends, the negative effects of mining growth show up on wages rather than employment.

${ }^{17}$ The bandwidth for log per capita GDP in the non-parametric regressions is 1 and the kernel is Gaussian.
} 
Figures $5 a-5 c$ indicate that manufacturing is strongly, significantly and positively associated with employment in the range of about $\$ 3000$ or $\$ 3500$ to just under $\$ 20,000$, with effects largest for upper middle-income countries as defined by the World Bank. For these countries, a 1 percent increase in aggregate growth due to manufacturing is associated with up to a 1 percent increase in the employment to population ratio and a comparable decline in the unemployment rate. In contrast, the correlation between natural resource growth and employment is far more evenly spread among the distribution (Figure 6a). Figure 6b, however, is suggestive of an unemployment effect even at low levels of GDP, which grows for upper middle-income countries. There is also suggestive evidence that mining growth may be associated with increased wages.

In contrast to manufacturing and mining, there is strikingly little evidence of strong effects of agricultural growth on employment growth or decline at low levels of income, where we would a priori expect such effects to be most significant (Figure 7a). Agricultural growth does appear to be associated with reduced unemployment among middle-income countries and surprisingly increased employment in high income countries. Estimated wage effects at low levels of income are also surprisingly small in magnitude, though in most cases wages are not defined for many in agriculture, so this may also reflect changes in the composition of the work force. Regardless, there is remarkably little evidence that agricultural growth is associated with improved labor market outcomes for low and lower-middle income countries.

To assess the possibility of a differential impact of export manufacturing on employment and wages, we combine data on export manufacturing from the World Bank's World Development Indicators database, and regress growth in employment outcomes on overall GDP growth and growth in export manufacturing (Table 9). Although export manufacturing does have an independent effect on employment outcomes, the point estimate is small. Sustained growth over five years at the $75^{\text {th }}$ percentile of growth in export manufacturing would correspond to a roughly one hundred percent change in export manufacturing output, and a 2.8 percentage point increase in employment rates. Growth in export manufacturing is also associated with a reduction in unemployment, but is weakly associated with wage growth. It is possible that episodes of growth in export manufacturing coincide with increases in overall openness to trade, which may introduce competitive pressures that prevent wages from growing. The nonparametric results (Figures 8a-8c) generally confirm these results, as effects on employment are generally positive but small, and there is no particularly strong effect for upper-middle income countries. Manufacturing exports are associated with reduced unemployment in middle income countries, but the effects are mild, and there is little effect of wages. Overall, the results suggest that the strong effects of manufacturing growth on employment and unemployment in middle income countries are mainly captured in overall growth, and there is little additional benefit from increasing manufacturing exports.

The evidence from Brazil is also consistent with a mild impact of manufacturing (Table 6). Although manufacturing is the only sector significantly associated with employment growth, a 1 percent increase in growth from manufacturing growth would lead to only a 0.05 percent increase in employment growth (point estimate significant at the 5 percent level). For unemployment, government, transport and communications, and mining growth are all associated with reductions in unemployment (at the 1 percent, 5 percent, and 10 percent level, respectively), which the largest effects for growth in government and transportation and communications. Looking at the point estimates on growth in the share of the population that is inactive, however, suggests that these effects on unemployment are largely driven by increased dropout from the labor force. We find no effects of individual sector growth on wage growth that are statistically significantly different from zero, and find roughly similar effects of growth in all sectors on growth in average labor productivity, although not all coefficients are sufficiently precisely estimated to be statistically distinguishable from zero. In sum, although the hypothesis that the coefficients are equal is rejected, the Brazilian evidence does not suggest large differential effects between the seven sectors. 
Within Indonesia, growth patterns suggest that agriculture growth has a strongly positive effect on employment growth, while growth in trade and commerce and growth in mining have significantly negative impacts on employment growth (Table 7). 1 percentage point of additional growth in agriculture is associated with 0.35 percentage points of additional employment growth (point estimate significant at the 5 percent level), while 1 percentage point of growth from additional growth in services is associated with a 0.38 percentage point reduction in employment growth (point estimate marginally significant at the 10 percent level). Consistent with the crosscountry results on a type of "resource curse", 1 additional percentage point of growth from mining is associated with both a 0.05 percentage point reduction in employment growth (significant at the 5 percent level) and a 0.12 percentage point reduction in log wage growth (marginally significant at the 10 percent level). In contrast, manufacturing growth is associated with large increases in wage growth, as the implied effect of a 1 percentage point increase in growth due to manufacturing is a 2.5 percent point increase in wages (significant at the 1 percent level). We can reject equality of effects on employment growth (test $p$-value $=0.004$ ) and of effects on wage growth (test $p$-value $=0.011$ ). Effects of 1-digit sector growth on labor productivity growth also vary, with the largest and most significant effects coming from growth in agriculture, trade and commerce, and construction. ${ }^{18}$

Within Mexico, growth in manufacturing and in finance is associated with significantly faster employment growth (estimates statistically significant at the 5 percent and 1 percent levels, respectively, Table 8). The magnitudes of the effects are fairly large, with a 1 percentage point increase in growth from manufacturing associated with a 0.24 percentage point increase in employment growth, and a 1 percentage point increase in growth from the financial sector associated with a 0.39 percentage point increase in employment growth. Only mining growth and growth in finance are significantly associated with a reduction in the growth of the share of the population out of the labor force, with a point estimate of 0.239 (significant at the 5 percent level) for mining and a point estimate of 0.333 (marginally significant at the 10 percent level) for finance. Faster growth due to growth in government and public administration and from growth in the financial sector is associated with much faster wage growth in Mexico. Faster productivity growth appears to follow from growth in agriculture, construction, and manufacturing in Mexico. Differences among coefficients are significant for only unemployment, wage growth, and productivity growth.

Overall we find little evidence that agriculture is a leading candidate to improve employment outcomes and raise wage growth, although in our analysis here we are netting out initial employment shares in order to test for compositional effects of growth. We do find evidence for effects of manufacturing growth on wage growth and employment growth in the cross-country analysis, and in each of the within-country analyses. We also find evidence for a "resource curse" reflected in employment outcomes in both the cross-country data and in Indonesia, although we find no evidence for such in Brazil or Mexico.

\section{Labor market mobility and long run growth effects}

The previous sections have described notable differences in sectoral growth patterns and employment outcomes, particularly with respect to differences between high and low productivity sectors, as well as growth in manufacturing and natural resources. Motivated by these findings, we next examine whether the effects of the

\footnotetext{
${ }^{18}$ In specifications including province-specific trends, growth in all sectors is similarly unemployment-reducing and has few other statistically significant effects on these outcomes, although as noted earlier, mining growth is associated with significantly slower wage growth.
} 
sectoral composition of growth on employment outcomes vary with measured labor mobility, or appear to be different over a much longer time horizon.

Table 10 shows the results of regressions where high and low productivity growth, again weighted by shares, are interacted with state or province level measures of average annual labor mobility. The measures of labor mobility are rough, and reflect the share of workers who report changing industries within one year.

In Brazil, Indonesia and Mexico, differences between the effects of high and low productivity sector growth on changes in employment outcomes appear to be largest in low-mobility states and provinces. These differences are greatly mitigated by increases in labor mobility. In particular, the point estimates on the interactions between sectoral growth and labor mobility imply that in all three countries, the effects of high and low productivity growth on changes in employment outcomes are roughly equal that in the most mobile states or provinces. These effects are most precisely estimated for employment growth and in Mexico. In Brazil, despite the fact that we are constrained by the coverage of the survey containing individual-level panel data on employment to only six states, we see similar qualitative patterns.

Although past studies come to conflicting conclusions on the role of regulations in restricting job mobility, a consensus has emerged that "employment protection regulations and related laws reduce gross labor mobility" (Freeman, 2010). We therefore examine cross-country data on labor regulation to see if policy-induced variation in labor mobility also mitigates the differential effects of sectoral growth. The results, presented in Table 11, give no indication that improvement in a country's Doing Business rank attenuates the effect of different sectoral growth patterns. We attribute this to the limited ability of the Doing Business measures to capture much of the underlying empirical variation in labor market mobility and flexibility.

Finally, we turn to the census data to estimate the long-run effects of growth composition on employment outcomes, after labor has an opportunity to adjust across sectors. The data from Brazil and Indonesia span four decades, from 1960 to 2000 and 1971 to 2010 respectively, while the Mexican data covers the 20 years from 1990 and 2010, with employment and output data at approximately 10 year intervals. The magnitudes of the point estimates on growth from agriculture, services, and industry are strikingly similar over longer horizons in Brazil, Indonesia and Mexico (Table 12). In the long run, it appears to make little difference whether state or provincial growth was led by agriculture, industry, or services. We therefore conclude that differences in the effects of growth in different sectors are largely mitigated by labor mobility.

\section{Conclusion}

Broad discussions on how policy can create more and better jobs in developing countries often spark debate on whether policy should aim to prioritize growth in particular economic sectors. Indeed, short-run patterns of sectoral growth appear to have disparate impacts on employment, wage and productivity growth around the developing world. In cross-country regressions, growth in less productive sectors, such as agriculture, construction, and retail and wholesale trade and other services, tend to lead to faster employment growth than growth in higher productivity sectors, such as manufacturing, finance and business services, and mining and utilities, with particularly noticeable effects for middle-income countries.

At the one digit level, the strongest effects are apparent in natural resources and manufacturing. Natural resource growth in the cross-country analysis, while contributing to reductions in employment for low-income countries, 
appears to harm labor markets in middle-income countries by reducing employment and increasing unemployment. Manufacturing growth appears to reduce employment for low-income countries, suggesting that these more productive jobs allow a greater share of workers to voluntarily exit the labor force. Manufacturing growth in middle-income countries, unlike natural resource growth, leads to large increases in employment and reductions in unemployment, both when comparing across countries and across Mexican and Brazilian states. This suggests that as countries develop, the stakes in the global competition for growth in labor-intensive sectors, particularly in manufacturing, rise.

In contrast to previous literature, we find little other evidence for special effects of growth in particular sectors, such as agriculture, on employment and wage growth. While growth in the financial sector is strongly associated with increased employment and wage growth in Mexico, there is little evidence for a special role for financial services growth in other contexts.

While growth in low productivity sectors may lead to faster employment growth, the evidence both within and across countries suggests that lower employment growth may be coupled with faster wage growth. This suggests that labor market rigidities may play a role in determining the distributional impacts of growth, both overall and in particular sectors. The specific impacts will depend on structural and institutional features of the industry as well as local labor markets, which may not be captured by standard measures of regulation. The varying patterns of sectoral growth on employment outcomes in the three country case studies of Brazil, Indonesia and Mexico are also consistent with a trade-off between wages and employment. To the extent that expansions in employment will differentially benefit the poor relative to increases in wages, holding employment fixed, we consider our main cross-country results consistent with the literature emphasizing the importance of labor-intensive (the inverse of productive) growth for poverty reduction around the world. ${ }^{19}$

We also find that measured labor mobility significantly attenuates differences in the impacts of growth composition on employment outcomes, as does examining the longer run. Taken together, our estimates suggest that in the short-run, and to the extent that wealth is accumulated in savings and assets over any transition path over the longer-run, differences in the sectoral composition of growth do have distributional implications, as they differentially bring the unemployed into the workforce, or raise the wages of those already employed. However, these differences may be dissipated by higher labor mobility and over longer time horizons.

Overall, our results suggest that in middle-income countries, the composition of growth as well as overall growth has at least a short-run effect on the growth of employment and wages. Composition effects are much smaller in low income contexts, and appear to dwindle over longer time horizons. This is consistent with arguments that focusing on overall growth rather than particular sectors may be an appropriate long-term policy objective (Kraay, 2006). Labor market mobility tends to attenuate these compositional effects, and promoting mobility between jobs may therefore be an important mechanism for more broadly distributing the benefits of growth originating in higher productivity and more capital-intensive sectors.

\footnotetext{
${ }^{19}$ Relatedly, Gutierrez et al (2007) find that the poverty impacts of employment intensity vary by sector, with productivity improvements necessary for poverty reduction in agriculture.
} 


\section{Acknowledgments}

This is a background paper for the 2013 World Development Report on Jobs. The authors would like to thank Arup Banerji, Kathleen Beegle, Samuel Freije, David Robalino and seminar participants in Washington DC and the East Asia and Pacific region for helpful comments and suggestions, as well as Claudio Montenegro and his team for compiling and providing the data. The views expressed in this paper are those of the authors and do not necessarily reflect those of the World Bank, its Board of Directors, or the countries they represent.

\section{References}

Amiti, Mary and Caroline Freund (2010). "The Anatomy of China's Export Growth." In China's Growing Role in World Trade. Eds. Robert Feenstra and Shang Jin Wei, National Bureau of Economic Research, Cambridge, MA.

Alvarez-Cuadrado, Francisco, and Markus Poschke (2011). "Structural Change Out of Agriculture: Labor Push versus Labor Pull." American Economic Journal: Macroeconomics, 3(3): 127-58.

Angrist, Joshua D., and Adriana D. Kugler (2008). "Rural Windfall or a New Resource Curse? Coca, Income, and Civil Conict in Colombia." The Review of Economics and Statistics, 90(2): 191\{215.

Balassa, Bela (1978). “Exports and Economic Growth.” Journal of Development Economics, 5:181-189.

Berg, Janine, Christopher Ernst and Peter Auer (2006). Meeting the Employment Challenge: Argentina, Brazil and Mexico in the Global Economy. International Labour Organization.

Caselli, Francesco and Guy Michaels (2009). “Do Oil Windfalls Improve Living Standards? Evidence from Brazil." NBER Working Papers 15550.

Chenery, Hollis and Moises Syrquin (1975). "Patterns of development, 1950-1970", Oxford University Press, London.

Christiaensen, Luc, Lionel Demery, and Jesper Kuhl (2011). "The (Evolving) Role of Agriculture in Poverty Reduction-An Empirical Perspective." Journal of Development Economics, 96(2): 239-254.

Datt, Gaurav and Martin Ravallion (2011). “Has India's Economic Growth Become More Pro-Poor in the Wake of Economic Reforms?” World Bank Economic Review, 25(2): 157-189.

De Janvry, Alain and Elizabeth Sadoulet (2009). “Agricultural Growth and Poverty Reduction: Additional Evidence." World Bank Research Observer, 25(1): 1-20.

Dube, Oeindrila and Juan Vargas (2012). "Commodity Prices and Civil Conflict: Evidence from Colombia." Forthcoming, Review of Economic Studies.

Ferreira, Francisco, Phillippe Leite, and Martin Ravallion (2010). “Poverty Reduction Without Economic Growth? Explaining Brazil's Poverty Dynamics, 1985-2004." Journal of Development Economics, 93(1): 20-36.

Foster, Andrew and Mark Rosenzweig (2007). "Economic Development and the Decline of Agricultural Employment." In Handbook of Development Economics, Volume 4. Eds. T Paul Schultz and John Strauss, Elsevier. 
Freeman, Richard B. (2010). "Labor Regulations, Unions, and Social Protection in Developing Countries: Market Distortions or Efficient Institutions?" In Dani Rodrik and Mark Rosenzweig (Eds.), Handbook of Development Economics (Vol. Volume 5, pp. 4657-4702), Elsevier: Amsterdam.

Freund, Caroline and Bob Rijkers (2012). “Employment Miracles.” Mimeo, World Bank.

Gollin, Douglas, Stephen L. Parente, and Richard Rogerson (2002). "The Role of Agriculture in Development." American Economic Review, 92(2): 160-164.

Gutierrez, Catalina, Carlo Orecchia, Pierella Paci, and Pieter Serneels (2007). “Does Employment Generation Really Matter for Poverty Reduction?” World Bank Policy Research Working Paper No. 4432.

Haggblade, S., Hazell, P., Reardon, T. (2002). "Strategies for Stimulating Poverty-Alleviating Growth in the Rural Non-farm Economy in Developing Countries." Mimeo, International Food Policy Research Institute, Washington, DC.

Headey, Derek, Dirk Bezemer and Peter B. Hazell (2010). "Agricultural Employment Trends in Asia and Africa: Too Fast or Too Slow?" World Bank Research Observer, 25(1): 57-89.

Kraay, Aart (2006). "When Is Growth Pro-poor? Evidence from a Panel of Countries." Journal of Development Economics, 80(1): 198-227.

Lanjouw, Jenny and Peter Lanjouw (2001). "The Rural Non-farm Sector: Issues and Evidence from Developing Countries." Agricultural Economics, 26 (1): 1-23.

Loayza, Norman and Claudio Raddatz (2010). "The Composition of Growth Matters for Poverty Alleviation." Journal of Development Economics, 93: 137-151.

McMillan, Margaret S. and Dani Rodrik (2012). "Globalization, Structural Change and Productivity Growth." NBER Working Paper 17143.

Montenegro, Claudio, and Maximillian Hirn (2009). "A New Disaggregated Set of Labor Market Indicators Using Standardized Household Surveys from Around the World", World Development Report Background Paper, available at: http://siteresources.worldbank.org/INTWDR2009/Resources/4231006-1204741572978/MontenegroHirn.pdf

Ravallion, Martin and Shaohua Chen (2007). "China's (Uneven) Progress Against Poverty." Journal of Development Economics, 82(1): 1-42.

Ravallion, Martin and Gaurav Datt (1996). “How Important to India's Poor is the Sectoral Composition of Economic Growth?" World Bank Economic Review, 10(1): 1-25.

Robinson, James, Ragnar Torvik, and Thierry Verdier (2006). "Political Foundations of the Resource Curse." Journal of Development Economics, 79(2): 447-468.

Sachs, Jeffrey D. and Andrew Warner (1995). "Natural Resource Abundance and Economic Growth." Harvard Institute for International Development, Development Discussion Paper No. 517.

Sachs, Jeffrey D. and Andrew Warner (1999). "The Big Push, Natural Resource Booms and Growth." Journal of Development Economics 59, 43- 76. 
Suryahadi, Asep, Daniel Suryadama, and Sudarno Sumarto (2009). "The Effects of Location and Sectoral Components of Economic Growth on Poverty: Evidence from Indonesia." Journal of Development Economics, 89(1): 109-117.

Thurlow, James and Peter Wobst (2006). "Not All Growth is Equally Good for the Poor: The Case of Zambia." Journal of African Economies, 15(4): 603-625.

Topalova, Petia (2008). “India: Is the Rising Tide Lifting All Boats? Issues 2008-2054." IMF Working Paper. International Monetary Fund, Washington, D.C.

Van der Ploeg, Frederick (2011). "Natural Resources: Curse or Blessing”, Journal of Economic Literature, 49:2, p. 366-420.

World Bank (2012). World Development Indicators. World Bank, Washington D.C. 
Figure 1a: Smoothed Employment to Population ratio by per capita GDP, 20002010

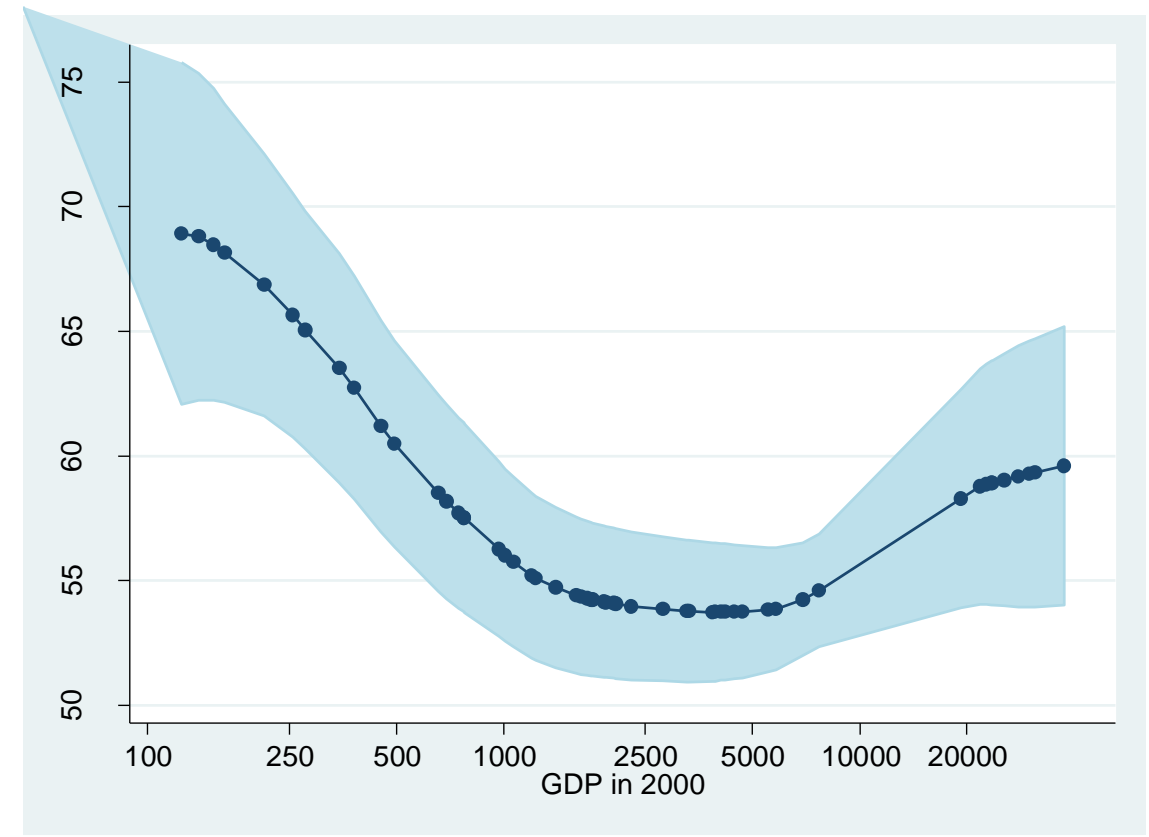

Notes: Each dot represents the average employment to population ratio from the mean of employment to population, locally weighted according to per capita GDP. The data consist of 62 countries for which the latest observed year for each country for surveys between 2000 and 2010.The bandwidth is 1, with an Epanchnikov kernel.

Figure 1b: Unemployment rate by per capita GDP, 2000-2010

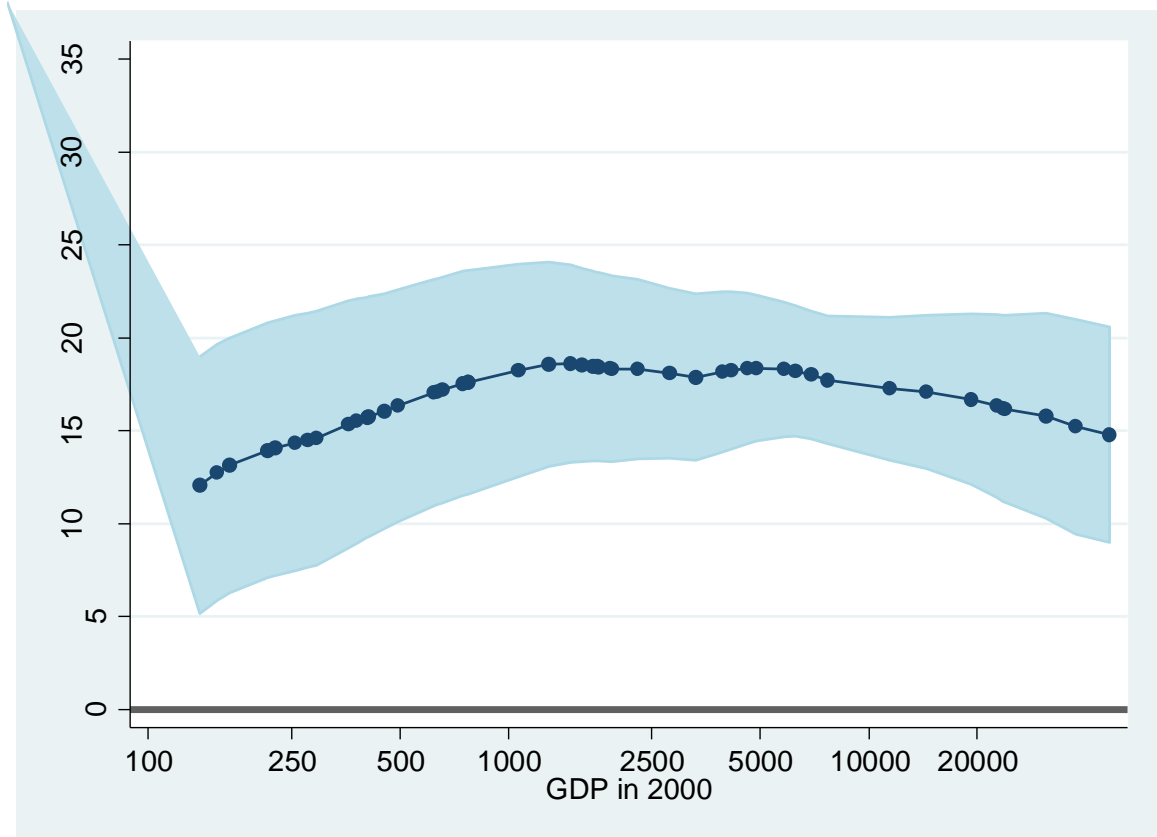

Note: See notes to figure 1 a 
Figure 2: Estimated impact of high and low productivity sector growth on employment to population ratio, by country GDP in 2000

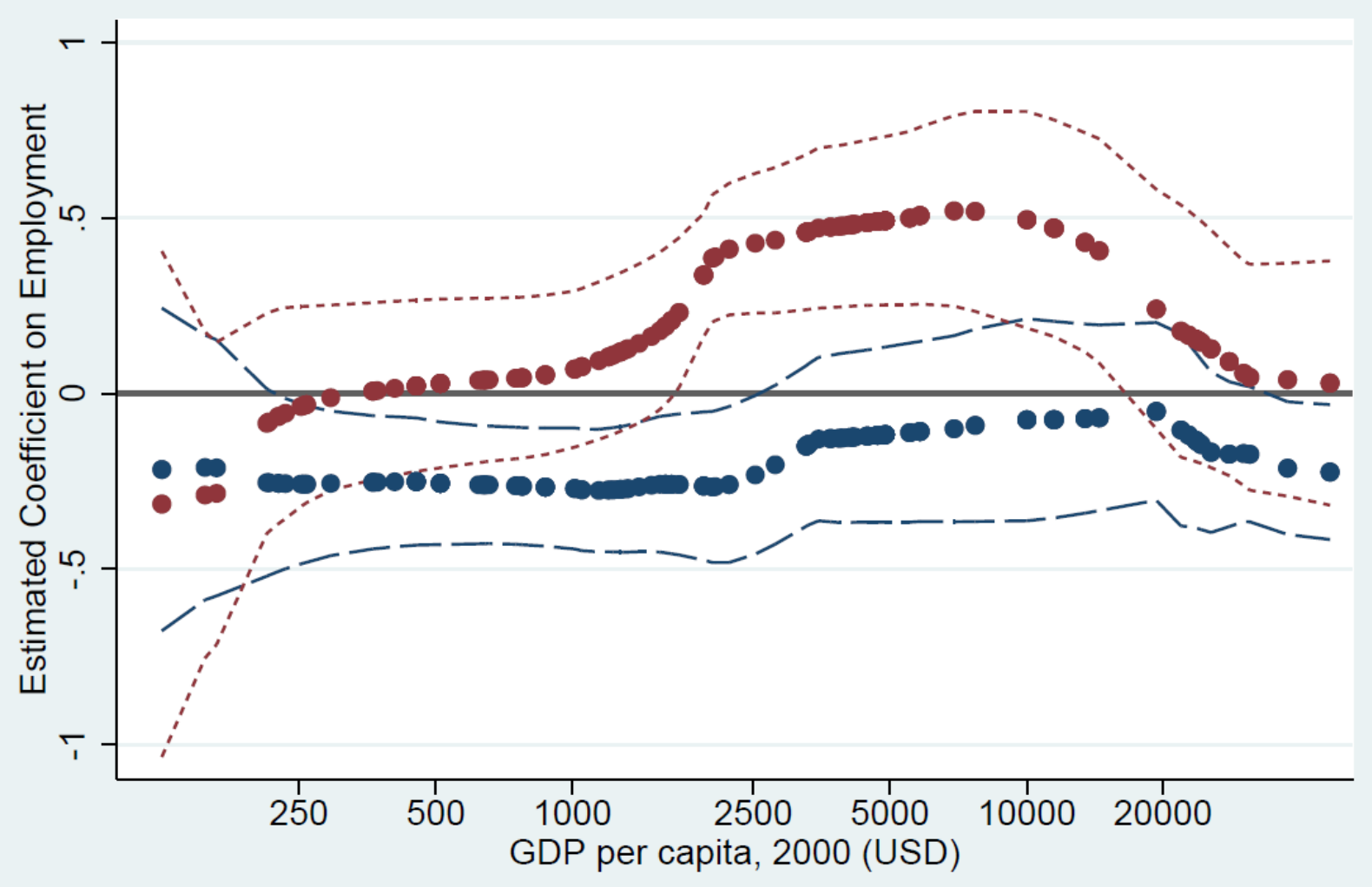

- High Productivity Sectors $\bullet$ Low Productivity Sectors

Notes: Each dot represents a coefficient estimate on from equation (2), locally weighted according to log per capita GDP in 2000 using a bandwidth of one and an Epanechnikov kernel. Dashed lines represent 95\% confidence intervals. Sectoral growth is weighted by its share of GDP. The coefficients represent the percentage point change in the employment to population ratio associated with the amount of additional growth in high or low productive sectors necessary to raise aggregate growth one percentage point. High-productivity sectors are manufacturing, transport and communications, finance, electricity and utilities, or mining. Low-productivity sectors are other services, agriculture, retail and wholesale trade, government and public administration, and construction. Standard errors are clustered on country. 
Figure 3: Estimated impact of high and low productivity sector growth on unemployment growth, by country GDP in 2000

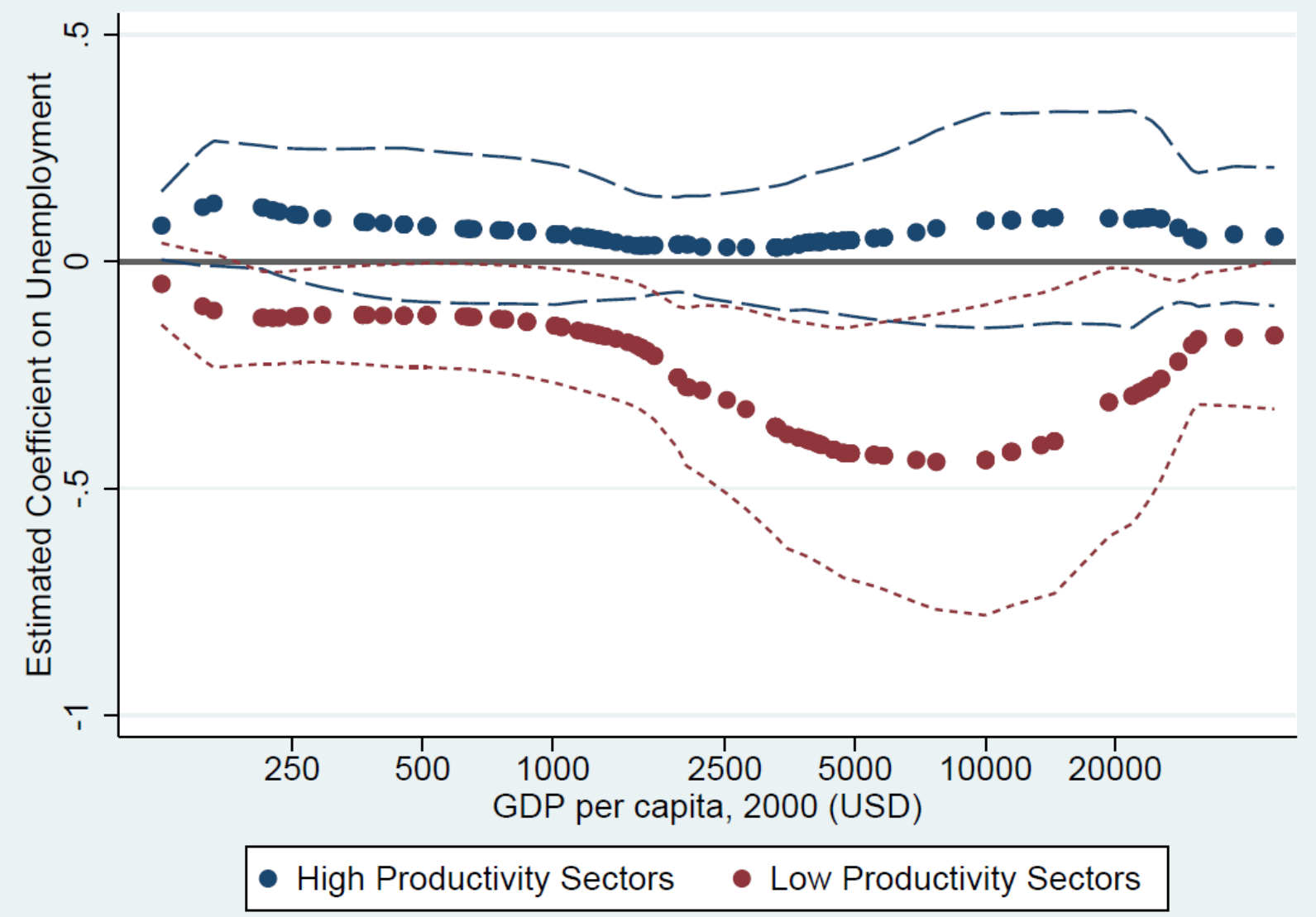

See notes to Figure 2. 
Figure 4: Estimated impact of high and low productivity sector growth on wage growth, by country GDP in 2000

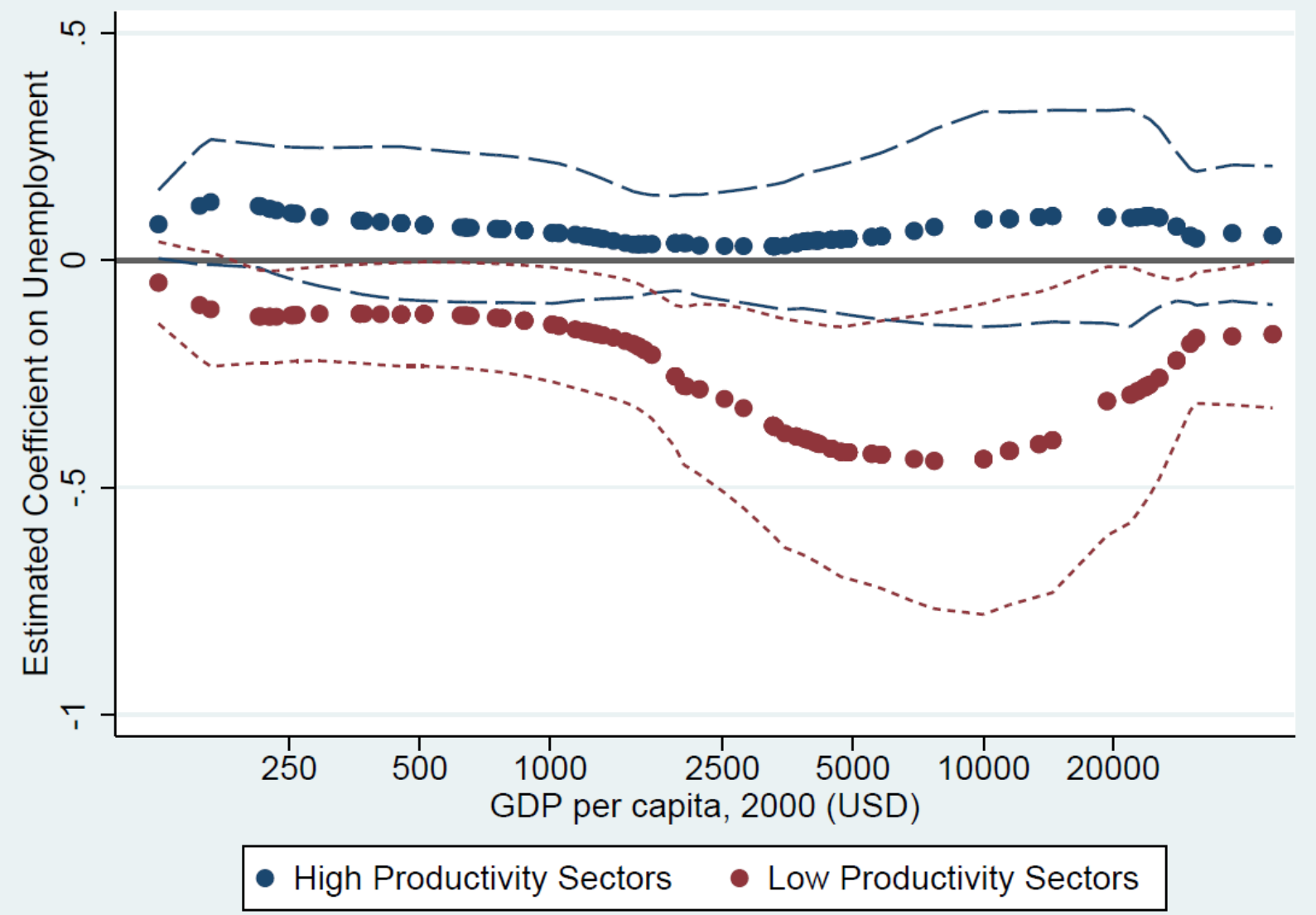

See notes to Figure 2. 
Figure 5a: Effects of manufacturing growth on employment growth, by country GDP in 2000

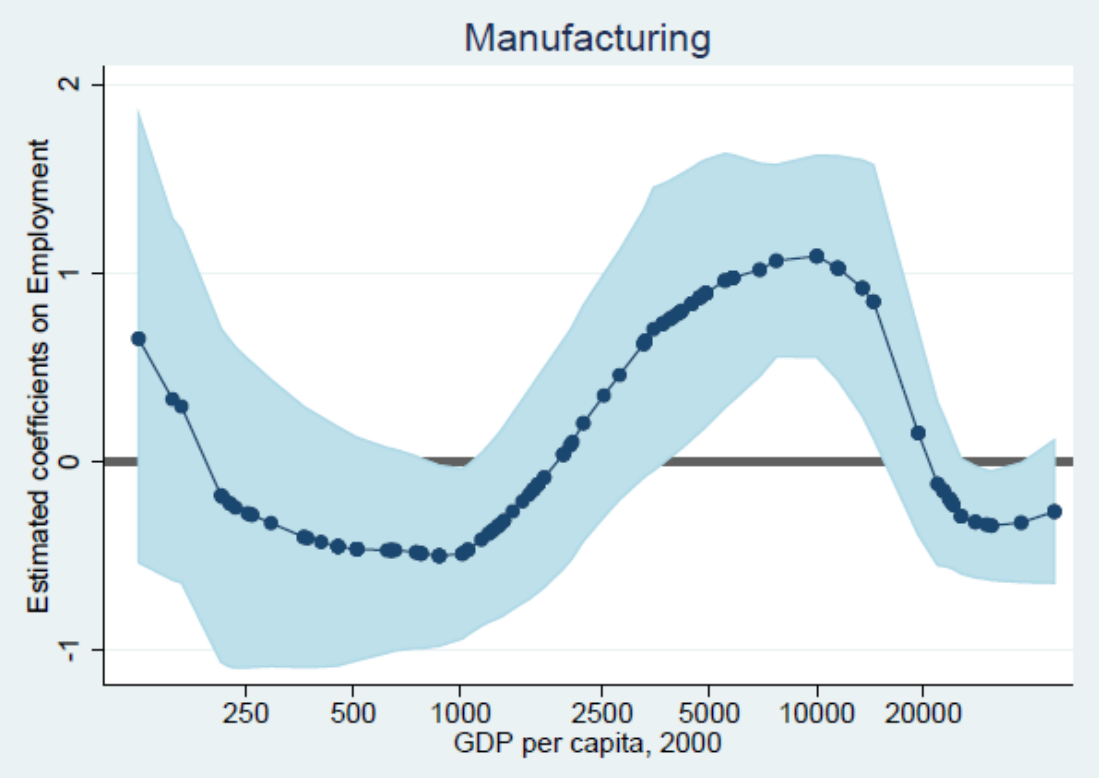

See notes to Figure 2.

Figure 5b: Effects of manufacturing growth on unemployment growth, by country GDP in 2000

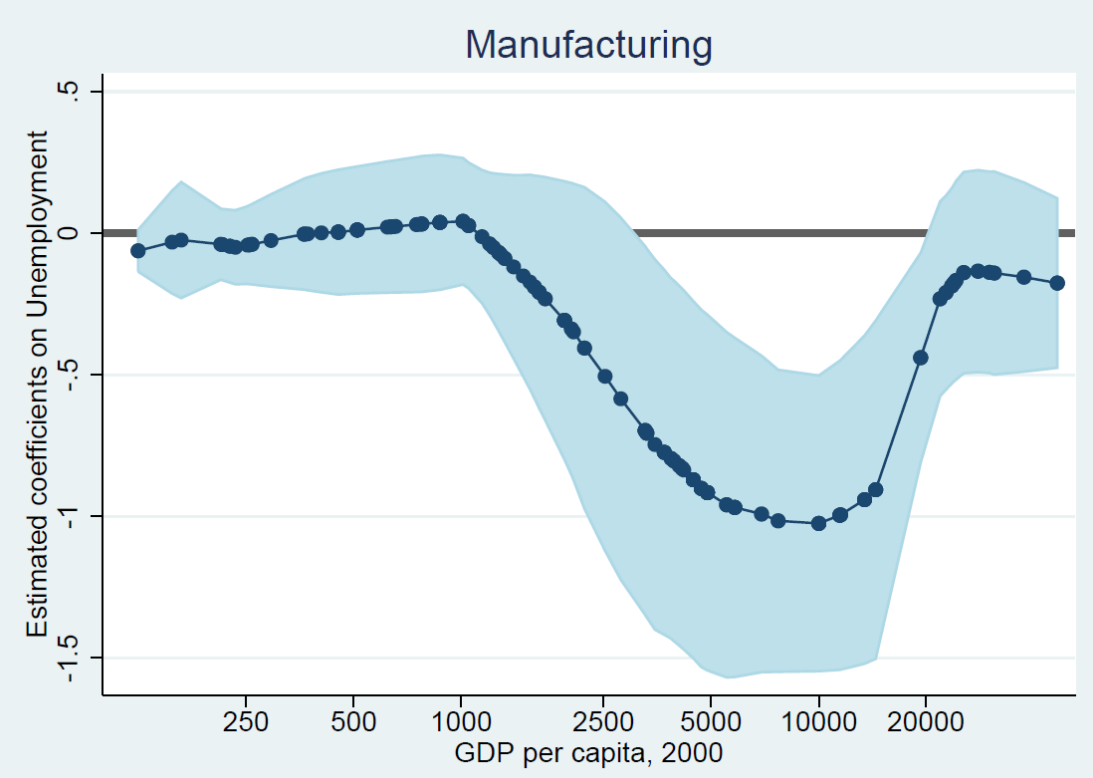

See notes to Figure 2. 
Figure 5c: Effects of manufacturing growth on wage growth, by country GDP in 2000

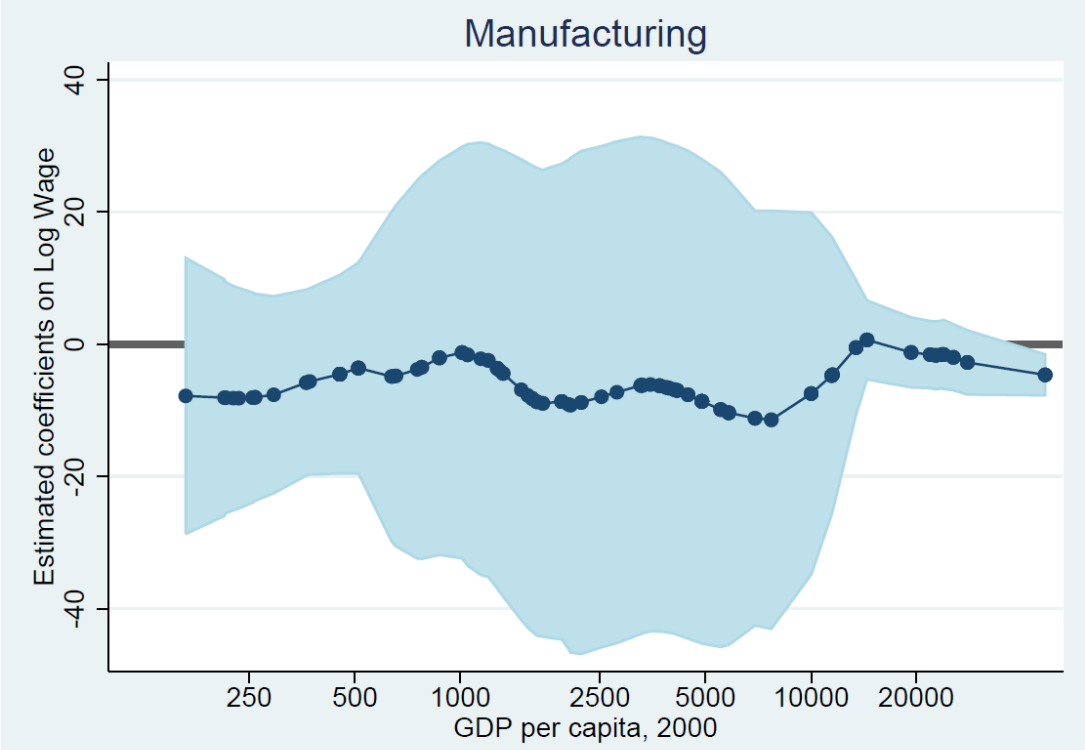

See notes to Figure 2. 
Figure 6a: Effects of mining growth on employment growth, by country GDP in 2000

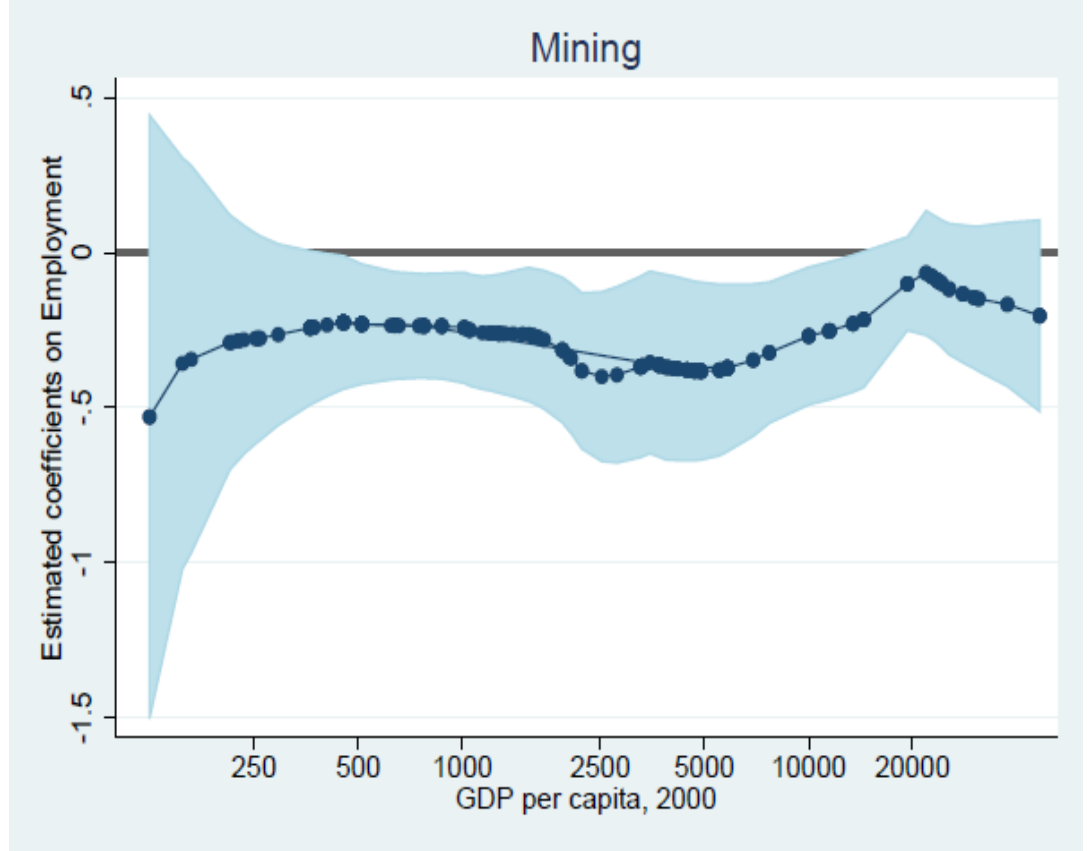

See notes to Figure 2.

Figure 6b: Effects of mining growth on unemployment growth, by country GDP in 2000

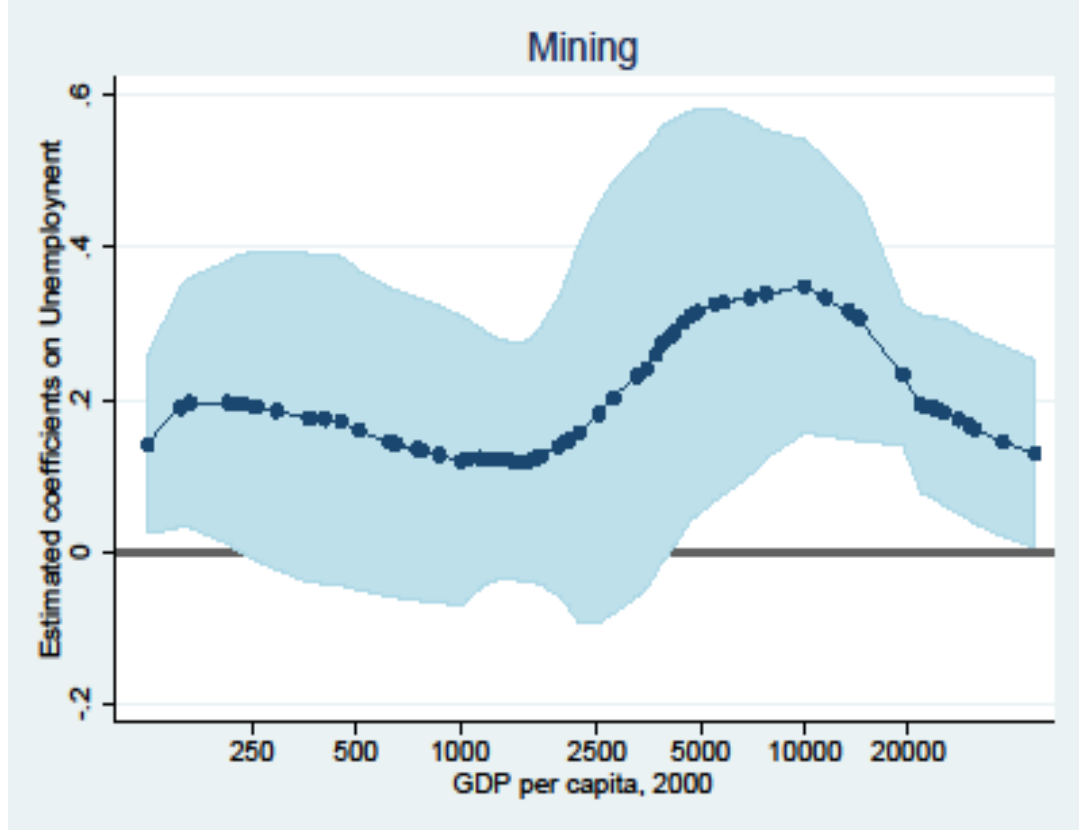

See notes to Figure 2. 
Figure 6c: Effects of mining growth on wages growth, by country GDP in 2000

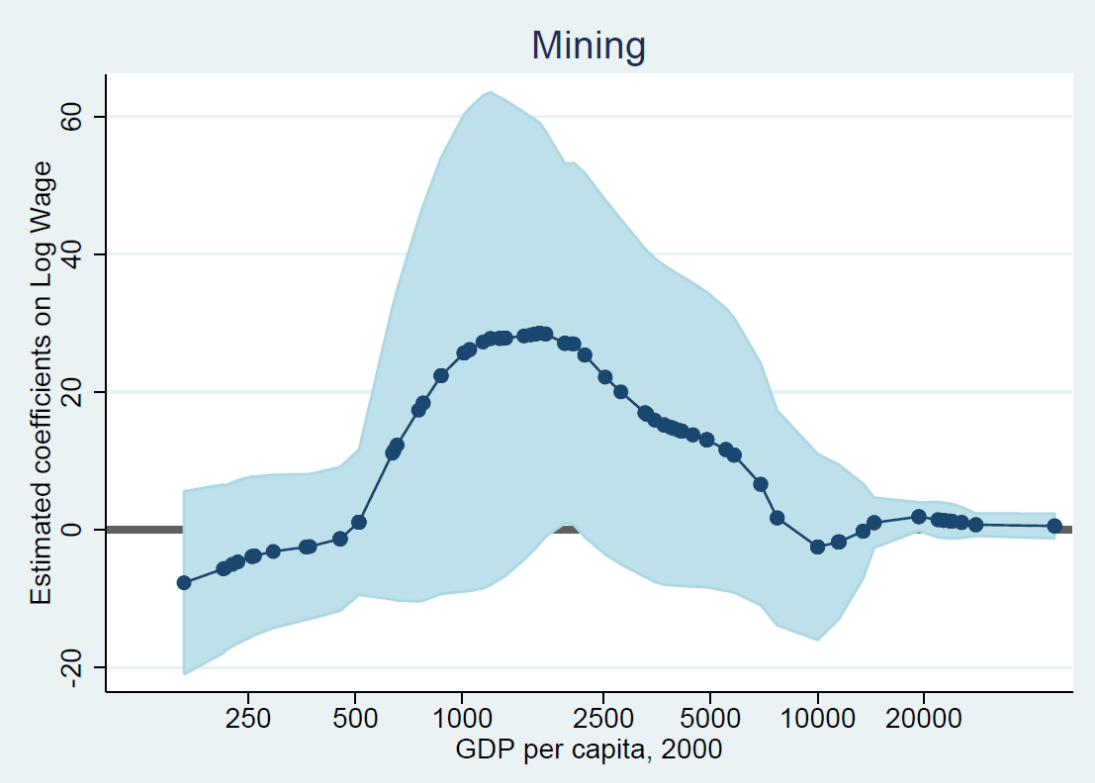

See notes to Figure 2. 
Figure 7a: Effects of agriculture growth on employment growth, by country GDP in 2000

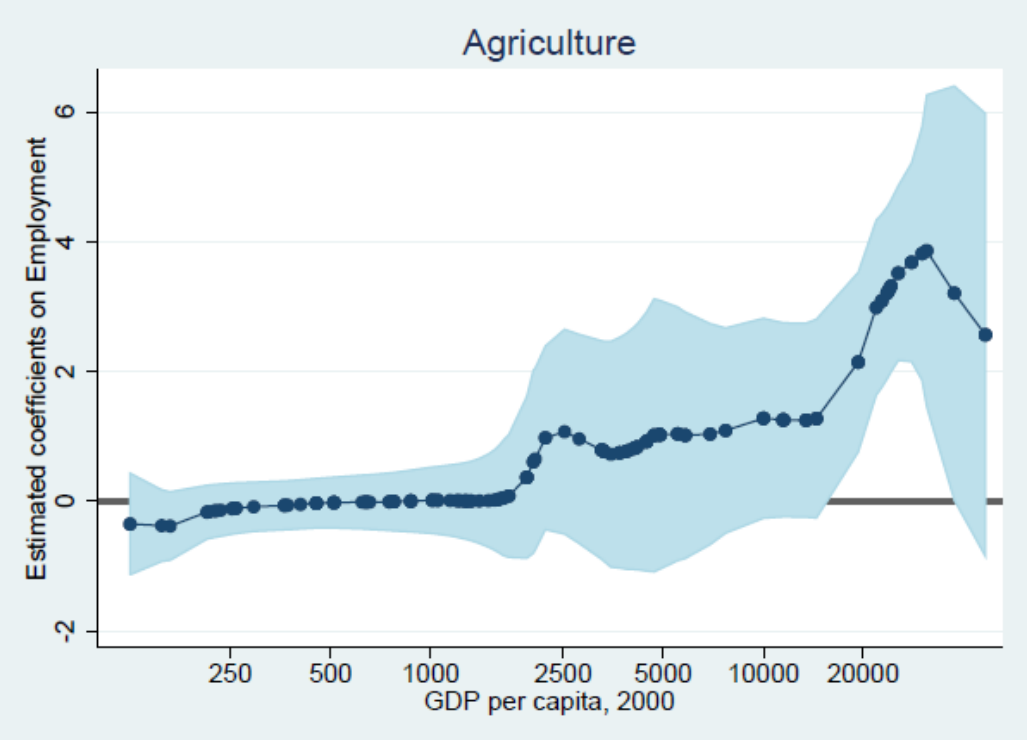

See notes to Figure 2.

Figure $7 \mathrm{~b}$ : Effects of agriculture growth on unemployment growth, by country GDP in 2000

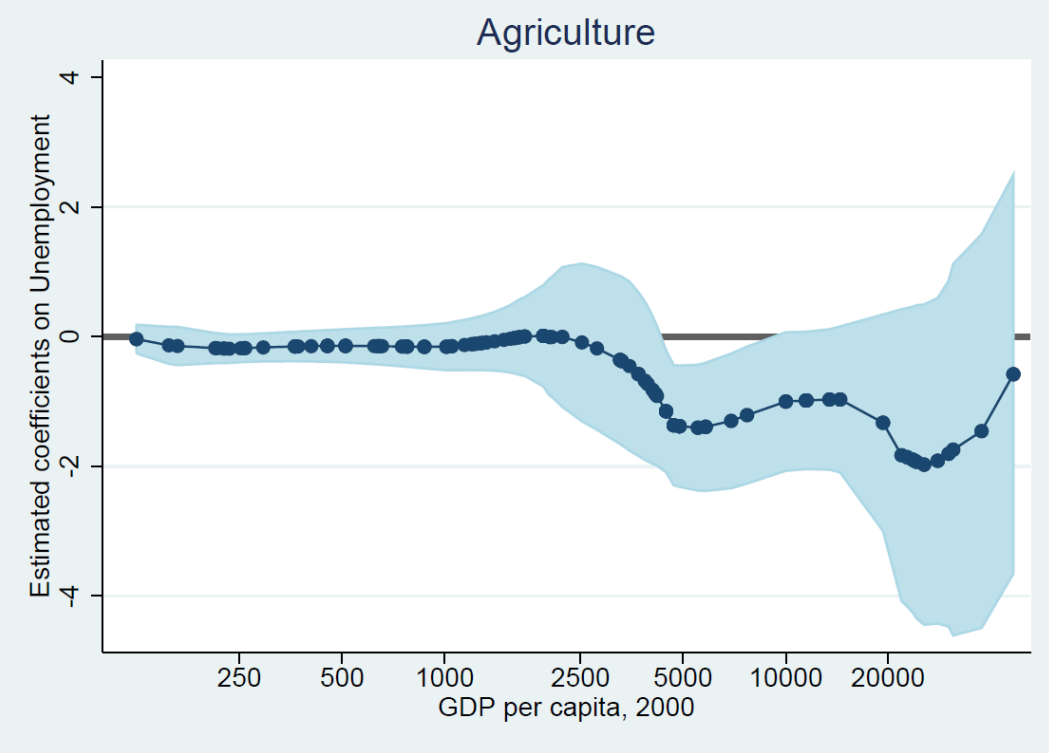

See notes to Figure 2. 
Figure 7c: Effects of agriculture growth on wage growth, by country GDP in 2000

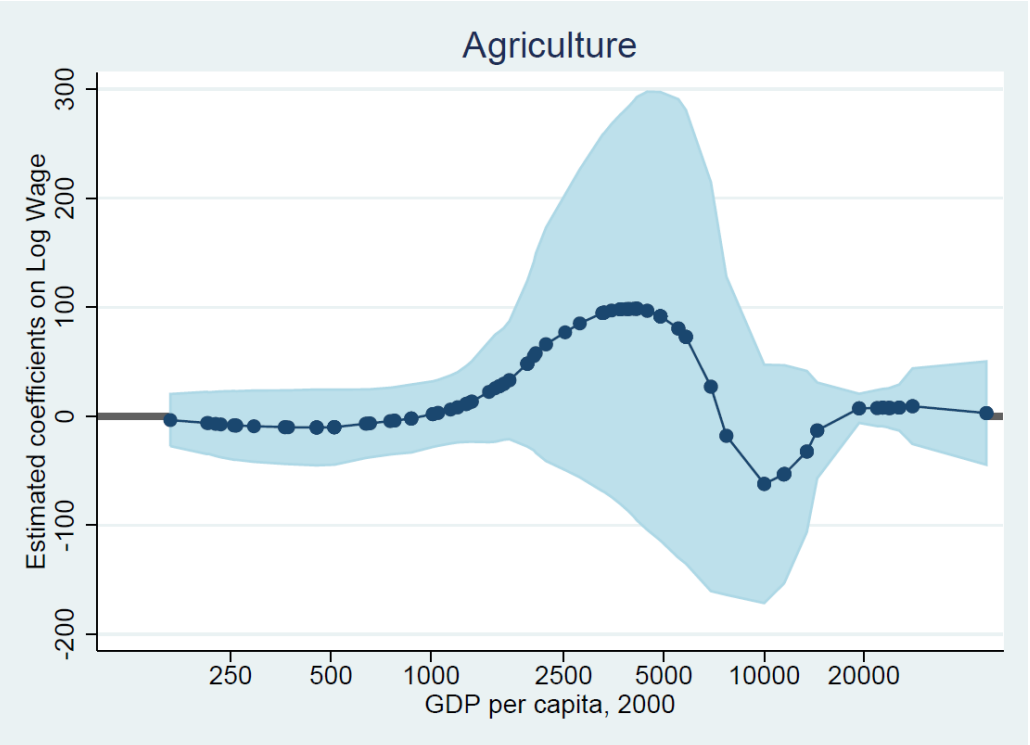

See notes to Figure 2. 
Figure 8a: Estimated effects of a 10 percent increase in manufacturing exports on employment to population, by country GDP in 2000

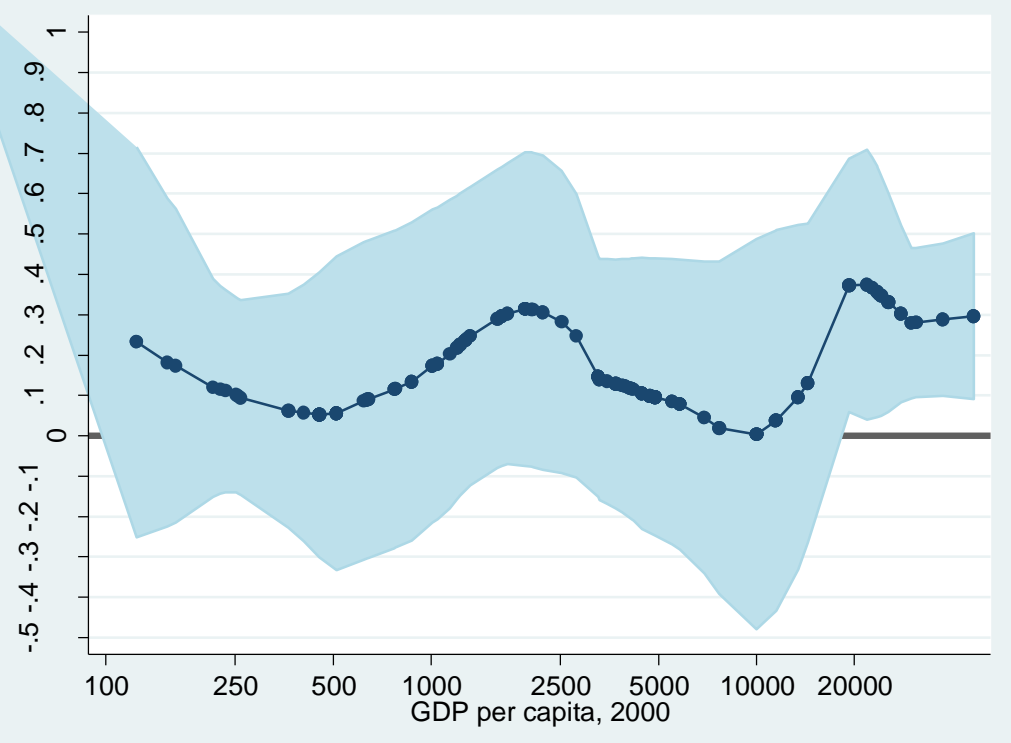

See notes to Figure 2.

Figure 8b: Estimated effects of a 10 percent increase in manufacturing exports on change in unemployment, by country per capita GDP in 2000

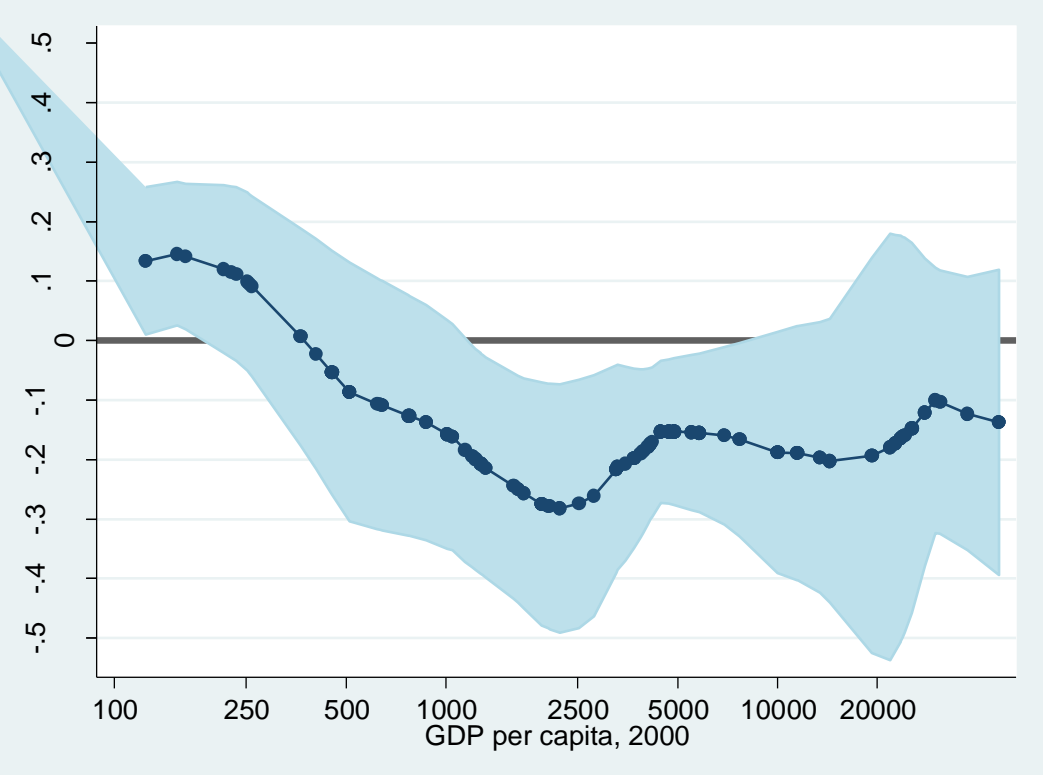

See notes to Figure 2. 
Figure 8c: Estimated effects of a 10 percent increase on wage growth, by country GDP in 2000

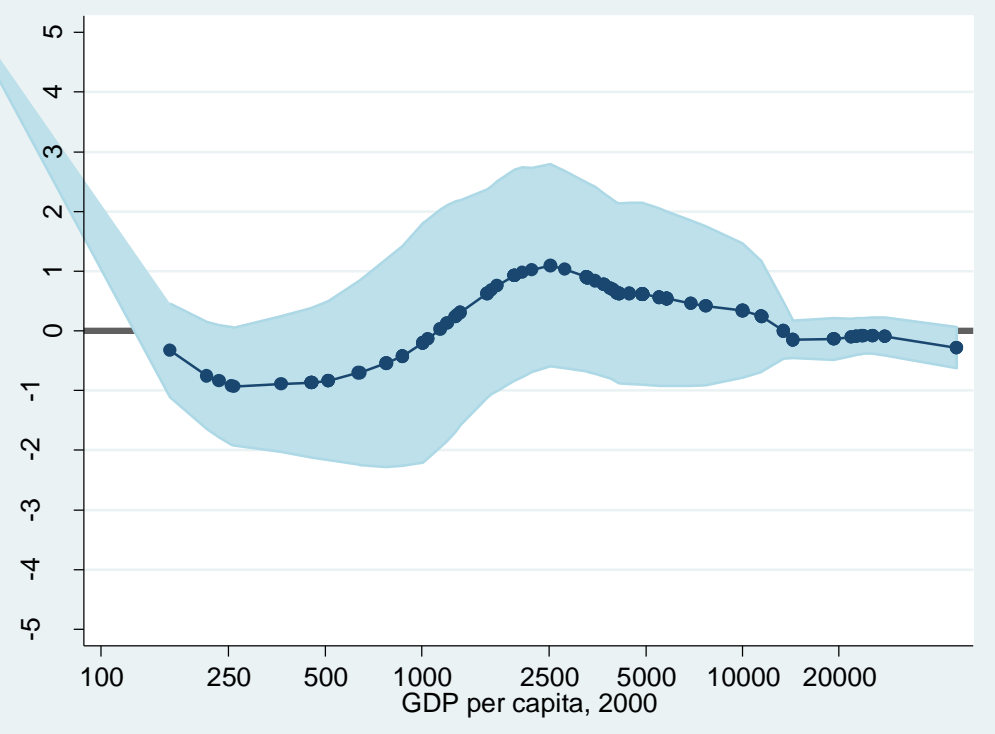


Table 1: Summary statistics

\begin{tabular}{|c|c|c|c|}
\hline Variable & $\mathbf{N}$ & Mean & Standard Deviation \\
\hline \multicolumn{4}{|l|}{ International } \\
\hline$\Delta$ Employed & 193 & -0.001 & 0.031 \\
\hline$\Delta$ Unemployed & 193 & -0.004 & 0.018 \\
\hline$\Delta$ Out of the labor force & 193 & 0.005 & 0.035 \\
\hline$\Delta \log ($ wages $)$ & 151 & -0.026 & 0.545 \\
\hline$\Delta$ Productivity & 151 & 0.067 & 0.648 \\
\hline High productivity growth & 193 & 0.018 & 0.017 \\
\hline Low productivity growth & 193 & 0.024 & 0.016 \\
\hline \multicolumn{4}{|l|}{ Brazil, 2003-2009 } \\
\hline$\Delta$ Employed & 825304 & 0.000 & 0.299 \\
\hline$\Delta$ Unemployed & 825304 & -0.001 & 0.283 \\
\hline$\Delta$ Out of the labor force & 825304 & 0.001 & 0.350 \\
\hline Log(wages) & 189 & 0.766 & 0.299 \\
\hline Productivity & 189 & 7.240 & 0.492 \\
\hline High productivity growth & 825304 & 0.016 & 0.022 \\
\hline Low productivity growth & 825304 & 0.021 & 0.023 \\
\hline \multicolumn{4}{|l|}{ Indonesia, 1988-2007 } \\
\hline$\Delta$ Employed & 383493 & 0.006 & 0.251 \\
\hline \multicolumn{4}{|l|}{ Unemployed } \\
\hline \multicolumn{4}{|l|}{ Out of the labor force } \\
\hline$\Delta \log ($ wages $)$ & 45603 & 0.109 & 0.599 \\
\hline$\Delta$ Productivity & 125851 & 0.021 & 0.258 \\
\hline High productivity growth & 383493 & 0.014 & 0.022 \\
\hline Low productivity growth & 383493 & 0.026 & 0.027 \\
\hline \multicolumn{4}{|l|}{ Mexico, 2005-2009 } \\
\hline$\Delta$ Employed & 331004 & 0.008 & 0.415 \\
\hline$\Delta$ Unemployed & 331004 & 0.003 & 0.203 \\
\hline$\Delta$ Out of the labor force & 331004 & -0.010 & 0.399 \\
\hline$\Delta \log ($ wages $)$ & 118384 & -0.002 & 0.689 \\
\hline$\Delta$ Productivity & 174661 & -0.002 & 0.585 \\
\hline High productivity growth & 331004 & 0.009 & 0.032 \\
\hline Low productivity growth & 331004 & 0.002 & 0.025 \\
\hline
\end{tabular}


Table 2: Cross-country regressions of annualized changes in employment outcomes on share-weighted annualized high and low productivity sector growth

\begin{tabular}{|c|c|c|c|c|c|}
\hline & $\begin{array}{c}\text { (I) } \\
\Delta \text { Employed }\end{array}$ & $\begin{array}{c}\text { (II) } \\
\Delta \text { Unemployed }\end{array}$ & $\begin{array}{c}\text { (III) } \\
\Delta \text { Out of the } \\
\text { labor force }\end{array}$ & $\begin{array}{c}\text { (IV) } \\
\Delta \log (\text { wages) }\end{array}$ & $\begin{array}{c}\text { (V) } \\
\Delta \text { Productivity }\end{array}$ \\
\hline \multicolumn{6}{|c|}{ High vs. low productivity sectors } \\
\hline \multirow[t]{2}{*}{ High productivity growth } & $-0.215^{* *}$ & 0.067 & $0.149 *$ & 3.818 & 1.364 \\
\hline & $(0.090)$ & $(0.054)$ & $(0.087)$ & $(7.428)$ & $(2.2566)$ \\
\hline \multirow[t]{2}{*}{ Low productivity growth } & 0.080 & $-0.162 * * *$ & 0.082 & 1.158 & -0.404 \\
\hline & $(0.110)$ & $(0.058)$ & $(0.092)$ & (5.329) & $(1.693)$ \\
\hline$p$-value, test: $\beta 1=\beta 2$ & 0.075 & 0.021 & 0.680 & 0.822 & 0.636 \\
\hline R-squared & 0.012 & 0.054 & 0.055 & 0.009 & 0.002 \\
\hline Observations & 193 & 193 & 193 & 151 & 151 \\
\hline
\end{tabular}

Note: High-productivity sectors are manufacturing, transport and communications, finance, electricity and utilities, or mining. Low-productivity sectors are other services, agriculture, retail and wholesale trade, government and public administration, and construction. Sectoral growth is weighted by its share of GDP. Standard errors are clustered on country. 
Table 3: Brazil, Indonesia and Mexico sector growth, high vs. low productivity sectors, annual changes

\begin{tabular}{|c|c|c|c|c|c|}
\hline & $\begin{array}{c}\text { (I) } \\
\Delta \text { Employed }\end{array}$ & $\begin{array}{c}\text { (II) } \\
\Delta \text { Unemployed }\end{array}$ & $\begin{array}{c}\text { (III) } \\
\Delta \text { Out of the } \\
\text { labor force }\end{array}$ & $\begin{array}{c}\text { (IV) } \\
\Delta \text { Log(wages) }\end{array}$ & $\begin{array}{c}(\mathrm{V}) \\
\Delta \text { Productivity }\end{array}$ \\
\hline \multicolumn{6}{|l|}{ Brazil, 2003-2009 } \\
\hline \multirow[t]{2}{*}{ High productivity growth } & 0.006 & $-0.031 * * *$ & 0.029 & 0.011 & $0.277^{* * *}$ \\
\hline & $(0.007)$ & $(0.005)$ & $(0.016)$ & $(0.037)$ & $(0.046)$ \\
\hline \multirow[t]{2}{*}{ Low productivity growth } & -0.005 & -0.019 & 0.006 & 0.029 & $0.254 * * *$ \\
\hline & $(0.009)$ & $(0.013)$ & $(0.023)$ & $(0.037)$ & $(0.040)$ \\
\hline$p$-value, test: $\beta 1=\beta 2$ & 0.384 & 0.274 & 0.526 & 0.256 & 0.250 \\
\hline R-squared & 0.000 & 0.000 & 0.000 & 0.991 & 0.985 \\
\hline Observations & 825304 & 825304 & 825304 & 189 & 189 \\
\hline \multicolumn{6}{|l|}{ Indonesia, 1988-2007 } \\
\hline \multirow[t]{2}{*}{ High productivity growth } & $-0.235^{*}$ & $-0.035 * *$ & $0.048 *$ & $1.790 * *$ & $0.714^{* *}$ \\
\hline & $(0.120)$ & $(0.013)$ & $(0.026)$ & $(0.607)$ & $(0.254)$ \\
\hline \multirow[t]{2}{*}{ Low productivity growth } & -0.017 & $-0.037 * *$ & $0.047^{*}$ & 0.022 & $1.339 * * *$ \\
\hline & $(0.074)$ & $(0.013)$ & $(0.026)$ & $(0.250)$ & $(0.110)$ \\
\hline$p$-value, test: $\beta 1=\beta 2$ & 0.061 & 0.165 & 0.775 & 0.010 & 0.036 \\
\hline R-squared & 0.020 & 0.046 & 0.186 & 0.049 & 0.057 \\
\hline Observations & 383493 & 2227036 & 2227036 & 45603 & 125851 \\
\hline \multicolumn{6}{|l|}{ Mexico, 2005-2009 } \\
\hline \multirow[t]{2}{*}{ High productivity growth } & $0.252 * * *$ & $-0.084 * *$ & $-0.168 * *$ & 0.002 & $0.347^{*}$ \\
\hline & $(0.074)$ & $(0.031)$ & $(0.063)$ & $(0.223)$ & $(0.190)$ \\
\hline \multirow[t]{2}{*}{ Low productivity growth } & 0.069 & -0.013 & 0.051 & 0.119 & $1.040 * * *$ \\
\hline & $(0.063)$ & $(0.066)$ & $(0.074)$ & $(0.192)$ & $(0.177)$ \\
\hline$p$-value, test: $\beta 1=\beta 2$ & 0.135 & 0.356 & 0.267 & 0.733 & 0.021 \\
\hline R-squared & 0.000 & 0.001 & 0.000 & 0.002 & 0.006 \\
\hline Observations & 331004 & 331004 & 331004 & 118284 & 174661 \\
\hline
\end{tabular}

Note: Individual level panel regressions in changes include year effects, and for state-year level regressions in columns (IV) and (V) for Brazil, state and year effects. Standard errors clustered on state or province. 
Table 4: Cross-country regressions of annualized changes in employment outcomes on share-weighted 1-digit sector growth

\begin{tabular}{|c|c|c|c|c|c|}
\hline & $\begin{array}{c}\text { (I) } \\
\Delta \text { Employed }\end{array}$ & $\begin{array}{c}\text { (II) } \\
\Delta \text { Unemployed }\end{array}$ & $\begin{array}{c}\text { (III) } \\
\Delta \text { Out of the } \\
\text { labor force }\end{array}$ & $\begin{array}{c}\text { (IV) } \\
\Delta \text { Log(wages) }\end{array}$ & $\begin{array}{c}\text { (V) } \\
\Delta \text { Productivity }\end{array}$ \\
\hline \multicolumn{6}{|l|}{ 1-digit sectors } \\
\hline \multirow[t]{2}{*}{ Agriculture growth } & -0.132 & -0.082 & 0.215 & 3.819 & 2.191 \\
\hline & $(0.192)$ & $(0.098)$ & $(0.249)$ & $(11.415)$ & (9.149) \\
\hline \multirow[t]{2}{*}{ Construction growth } & 0.212 & -0.040 & -0.173 & 23.054 & 3.871 \\
\hline & $(0.331)$ & $(0.187)$ & $(0.305)$ & $(18.181)$ & $(11.163)$ \\
\hline Retail and wholesale trade & -0.152 & -0.185 & 0.337 & -10.507 & $18.324^{*}$ \\
\hline growth & $(0.315)$ & $(0.305)$ & $(0.234)$ & $(9.846)$ & $(10.438)$ \\
\hline Transport and communications & -0.078 & -0.421 & 0.499 & -48.80 & 19.679 \\
\hline growth & $(0.424)$ & $(0.275)$ & $(0.390)$ & (34.913) & $(18.062)$ \\
\hline \multirow[t]{2}{*}{ Manufacturing growth } & 0.047 & -0.259 & 0.223 & -4.395 & -3.957 \\
\hline & $(0.278)$ & $(0.176)$ & $(0.305)$ & $(11.829)$ & $(11.176)$ \\
\hline \multirow[t]{2}{*}{ Mining and utilities growth } & $-0.301 * * *$ & $0.198 * * *$ & 0.103 & 9.391 & -0.192 \\
\hline & $(0.110)$ & $(0.070)$ & $(0.102)$ & $(10.923)$ & $(3.840)$ \\
\hline \multirow[t]{2}{*}{ Other growth } & 0.102 & 0.035 & -0.137 & $17.862 * *$ & -17.457 \\
\hline & $(0.255)$ & $(0.167)$ & $(0.192)$ & $(8.779)$ & $(10.935)$ \\
\hline$p$-value, test: $\beta 1=\beta 2=\ldots=\beta 7$ & 0.317 & 0.020 & 0.325 & 0.071 & 0.247 \\
\hline R-squared & 0.063 & 0.142 & 0.075 & 0.083 & 0.057 \\
\hline Observations & 193 & 193 & 193 & 151 & 151 \\
\hline
\end{tabular}

Note: Standard errors clustered on country. 
Table 5: Share of employees that are paid or non-agricultural, cross-country regressions

\begin{tabular}{|c|c|c|c|c|}
\hline & $\begin{array}{c}\text { (I) } \\
\Delta \text { Share Wage } \\
\text { Employee }\end{array}$ & $\begin{array}{c}\text { (II) } \\
\Delta \text { Share Wage } \\
\text { Employee or } \\
\text { Employer }\end{array}$ & $\begin{array}{c}\text { (III) } \\
\Delta \text { Share Wage } \\
\text { Employee, } \\
\text { Employer, or Self- } \\
\text { Employed }\end{array}$ & $\begin{array}{c}\text { (IV) } \\
\Delta \text { Non- } \\
\text { agricultural } \\
\text { employment }\end{array}$ \\
\hline \multicolumn{5}{|l|}{ High vs. low productivity sectors } \\
\hline \multirow[t]{2}{*}{ High productivity growth } & 0.262 & 0.368 & $0.165^{*}$ & 0.150 \\
\hline & $(0.275)$ & $(0.342)$ & $(0.088)$ & $(0.189)$ \\
\hline \multirow[t]{2}{*}{ Low productivity growth } & -0.271 & $-0.681 * *$ & -0.050 & 0.066 \\
\hline & $(0.211)$ & $(0.298)$ & $(0.099)$ & $(0.100)$ \\
\hline$p$-value, test: $\beta 1=\beta 2$ & 0.170 & 0.007 & 0.192 & 0.758 \\
\hline R-squared & 0.010 & 0.021 & 0.026 & 0.016 \\
\hline Observations & 187 & 180 & 153 & 172 \\
\hline \multicolumn{5}{|l|}{ 1-digit sectors } \\
\hline \multirow[t]{2}{*}{ Agriculture growth } & -1.103 & -4.012 & 0.094 & -0.277 \\
\hline & $(1.045)$ & $(2.648)$ & $(0.212)$ & $(0.612)$ \\
\hline \multirow[t]{2}{*}{ Construction growth } & 1.628 & 2.507 & 0.035 & 0.191 \\
\hline & $(1.261)$ & $(2.493)$ & $(0.432)$ & $(0.423)$ \\
\hline Retail and wholesale trade & -1.108 & -0.406 & $0.571 * *$ & 0.618 \\
\hline growth & $(1.279)$ & $(1.575)$ & $(0.281)$ & $(0.424)$ \\
\hline Transport and communications & -3.792 & -4.839 & -0.027 & 1.114 \\
\hline growth & (1.939) & (3.944) & $(0.501)$ & $(1.081)$ \\
\hline \multirow[t]{2}{*}{ Manufacturing growth } & -0.294 & -0.473 & -0.203 & 0.442 \\
\hline & $(0.480)$ & $(0.603)$ & $(0.226)$ & $(0.366)$ \\
\hline \multirow[t]{2}{*}{ Mining and utilities growth } & 0.583 & 0.601 & $0.275^{* * *}$ & -0.047 \\
\hline & $(0.396)$ & $(0.503)$ & $(0.099)$ & $(0.321)$ \\
\hline \multirow[t]{2}{*}{ Other growth } & 1.145 & 0.910 & -0.316 & $-0.634^{*}$ \\
\hline & $(0.739)$ & (1.359) & $(0.268)$ & $(0.379)$ \\
\hline$p$-value, test: $\beta 1=\beta 2=\ldots=\beta 7$ & 0.300 & 0.085 & 0.357 & 0.299 \\
\hline R-squared & 0.133 & 0.157 & 0.082 & 0.077 \\
\hline Observations & 187 & 180 & 153 & 172 \\
\hline
\end{tabular}


Table 6: Brazil sector growth, 1-digit sectors, annual changes 2003-2009

\begin{tabular}{|c|c|c|c|c|c|}
\hline & $\begin{array}{c}\text { (I) } \\
\Delta \text { Employed }\end{array}$ & $\begin{array}{c}\text { (II) } \\
\Delta \text { Unemployed }\end{array}$ & $\begin{array}{c}\text { (III) } \\
\Delta \text { Out of the } \\
\text { labor force }\end{array}$ & $\begin{array}{c}\text { (IV) } \\
\Delta \text { Log(wages) }\end{array}$ & $\begin{array}{c}(\mathrm{V}) \\
\Delta \text { Productivity }\end{array}$ \\
\hline \multicolumn{6}{|l|}{ 1-digit sectors } \\
\hline \multirow[t]{2}{*}{ Other services } & -0.025 & $-0.065^{*}$ & 0.034 & 0.019 & 0.105 \\
\hline & $(0.038)$ & $(0.027)$ & $(0.042)$ & $(0.050)$ & $(0.090)$ \\
\hline \multirow[t]{2}{*}{ Agriculture } & -0.013 & 0.018 & -0.046 & 0.008 & $0.217 * * *$ \\
\hline & $(0.064)$ & $(0.039)$ & $(0.057)$ & $(0.044)$ & $(0.048)$ \\
\hline Retail and wholesale & 0.046 & 0.008 & -0.064 & 0.049 & $0.170 * *$ \\
\hline trade & $(0.067)$ & $(0.070)$ & $(0.102)$ & $(0.045)$ & $(0.068)$ \\
\hline Government, public & -0.037 & $-0.250 * * *$ & $0.246 * * *$ & 0.071 & 0.098 \\
\hline administration & $(0.042)$ & $(0.043)$ & $(0.038)$ & $(0.066)$ & $(0.073)$ \\
\hline \multirow[t]{2}{*}{ Construction } & -0.168 & 0.040 & 0.076 & 0.096 & $0.332 * * *$ \\
\hline & $(0.102)$ & $(0.134)$ & $(0.091)$ & $(0.063)$ & $(0.108)$ \\
\hline \multirow[t]{2}{*}{ Manufacturing } & $0.052 * *$ & -0.027 & 0.033 & 0.053 & $0.233^{* * *}$ \\
\hline & $(0.015)$ & $(0.016)$ & $(0.027)$ & $(0.046)$ & $(0.057)$ \\
\hline Transport and & -0.097 & $-0.200 * *$ & 0.213 & -0.109 & 0.144 \\
\hline communications & $(0.092)$ & $(0.077)$ & $(0.224)$ & $(0.082)$ & $(0.088)$ \\
\hline \multirow[t]{2}{*}{ Utilities } & 0.099 & 0.167 & 0.117 & 0.069 & 0.147 \\
\hline & $(0.086)$ & $(0.103)$ & $(0.084)$ & $(0.078)$ & $(0.101)$ \\
\hline Finance and business & -0.047 & 0.038 & 0.033 & -0.036 & $0.157^{* *}$ \\
\hline services & $(0.038)$ & $(0.063)$ & $(0.042)$ & $(0.077)$ & $(0.066)$ \\
\hline \multirow[t]{2}{*}{ Mining } & -0.016 & $-0.037^{*}$ & 0.044 & 0.008 & $0.182 * * *$ \\
\hline & $(0.014)$ & $(0.018)$ & $(0.026)$ & $(0.046)$ & $(0.063)$ \\
\hline$p$-value, test: $\beta 1=\beta 2=\ldots=\beta 10$ & 0.070 & 0.000 & 0.005 & 0.000 & 0.010 \\
\hline R-squared & 0.000 & 0.000 & 0.000 & 0.993 & 0.987 \\
\hline Observations & 825304 & 825304 & 825304 & 189 & 189 \\
\hline
\end{tabular}

Note: Individual level panel regressions in changes include year effects. Standard errors clustered on state or province. 
Table 7: Cross-province regressions of annualized changes in employment outcomes on share-weighted annualized 1-digit sector growth, Indonesia, 1988-2007

\begin{tabular}{|c|c|c|c|c|c|}
\hline & $\begin{array}{c}\text { (I) } \\
\Delta \text { Employed }\end{array}$ & $\begin{array}{c}\text { (II) } \\
\Delta \\
\text { Unemployed }\end{array}$ & $\begin{array}{c}\text { (III) } \\
\Delta \text { Out of the } \\
\text { labor force }\end{array}$ & $\begin{array}{c}\text { (IV) } \\
\Delta \text { Log(wages) }\end{array}$ & $\begin{array}{c}(\mathrm{V}) \\
\Delta \text { Productivity }\end{array}$ \\
\hline 1-digit sectors & & & & & \\
\hline Other services & $\begin{array}{c}0.391 \\
(0.300)\end{array}$ & $\begin{array}{l}-0.034 \\
(0.023)\end{array}$ & $\begin{array}{l}0.065 * * \\
(0.028)\end{array}$ & $\begin{array}{c}2.312 \\
(3.781)\end{array}$ & $\begin{array}{r}0.479 \\
(1.281)\end{array}$ \\
\hline Agriculture & $\begin{array}{l}0.349 * * \\
(0.150)\end{array}$ & $\begin{array}{l}-0.024 \\
(0.020)\end{array}$ & $\begin{array}{c}0.054 * \\
(0.030)\end{array}$ & $\begin{array}{c}1.037 \\
(0.767)\end{array}$ & $\begin{array}{l}1.494^{* *} \\
(0.536)\end{array}$ \\
\hline Trade and commerce & $\begin{array}{l}-0.387^{*} \\
(0.195)\end{array}$ & $\begin{array}{l}-0.025 \\
(0.020)\end{array}$ & $\begin{array}{c}0.052 * \\
(0.027)\end{array}$ & $\begin{array}{l}-0.716 \\
(0.681)\end{array}$ & $\begin{array}{c}1.567 * * * \\
(0.275)\end{array}$ \\
\hline Construction & $\begin{array}{l}-0.499 \\
(0.506)\end{array}$ & $\begin{array}{l}-0.033 \\
(0.025)\end{array}$ & $\begin{array}{r}0.068 \\
(0.027)\end{array}$ & $\begin{array}{l}-0.363 \\
(2.425)\end{array}$ & $\begin{array}{l}2.145 * * \\
(0.932)\end{array}$ \\
\hline Manufacturing & $\begin{array}{l}-0.120 \\
(0.132)\end{array}$ & $\begin{array}{l}-0.025 \\
(0.020)\end{array}$ & $\begin{array}{c}0.053 * \\
(0.029)\end{array}$ & $\begin{array}{c}2.484 * * * \\
(0.562)\end{array}$ & $\begin{array}{c}0.574 * \\
(0.298)\end{array}$ \\
\hline Transport & $\begin{array}{c}0.325 \\
(0.732)\end{array}$ & $\begin{array}{l}-0.036 \\
(0.023)\end{array}$ & $\begin{array}{c}0.056 \\
(0.036)\end{array}$ & $\begin{array}{c}1.775 \\
(3.128)\end{array}$ & $\begin{array}{c}0.021 \\
(1.271)\end{array}$ \\
\hline Finance & $\begin{array}{l}-0.412 \\
(0.418)\end{array}$ & $\begin{array}{l}-0.025 \\
(0.023)\end{array}$ & $\begin{array}{l}0.065 * * \\
(0.026)\end{array}$ & $\begin{array}{l}-4.093 \\
(3.153)\end{array}$ & $\begin{array}{c}1.505 \\
(0.931)\end{array}$ \\
\hline Electricity & $\begin{array}{l}-0.862 \\
(1.071)\end{array}$ & $\begin{array}{l}-0.039 \\
(0.059)\end{array}$ & $\begin{array}{c}0.137^{*} \\
(0.068)\end{array}$ & $\begin{array}{l}-5.261 \\
(6.276)\end{array}$ & $\begin{array}{r}0.016 \\
(3.577)\end{array}$ \\
\hline Mining & $\begin{array}{c}-0.054^{* *} \\
(0.025)\end{array}$ & $\begin{array}{l}-0.026 \\
(0.020)\end{array}$ & $\begin{array}{c}0.057^{*} \\
(0.028)\end{array}$ & $\begin{array}{l}-0.122 * \\
(0.065)\end{array}$ & $\begin{array}{l}0.078 * * \\
(0.029)\end{array}$ \\
\hline$p$-value, test: $\beta 1=\beta 2=\ldots=\beta 9$ & 0.004 & 0.021 & 0.051 & 0.011 & 0.000 \\
\hline R-squared & 0.020 & 0.046 & 0.186 & 0.051 & 0.059 \\
\hline Observations & 381629 & 2227036 & 2227036 & 44894 & 125338 \\
\hline
\end{tabular}

Note: Individual level panel regressions in changes include year effects. Standard errors clustered on state or province. 
Table 8: Cross-state regressions of annualized changes in employment outcomes on share-weighted annualized high and low productivity sector growth, Mexico

\begin{tabular}{|c|c|c|c|c|c|}
\hline & $\begin{array}{c}\text { (I) } \\
\Delta \text { Employed }\end{array}$ & $\begin{array}{c}\text { (II) } \\
\Delta \text { Unemployed }\end{array}$ & $\begin{array}{c}\text { (III) } \\
\Delta \text { Out of the } \\
\text { labor force }\end{array}$ & $\begin{array}{c}\text { (IV) } \\
\Delta \text { Log(wages) }\end{array}$ & $\begin{array}{c}\text { (III) } \\
\Delta \text { Productivity }\end{array}$ \\
\hline \multicolumn{6}{|l|}{ 1-digit sectors } \\
\hline \multirow[t]{2}{*}{ Other services } & 1.112 & -0.490 & -0.739 & -3.972 & 2.283 \\
\hline & $(1.834)$ & $(0.558)$ & $(1.982)$ & $(7.636)$ & $(2.867)$ \\
\hline \multirow[t]{2}{*}{ Agriculture } & 0.058 & 0.224 & -0.287 & 1.441 & $2.694 * * *$ \\
\hline & $(0.257)$ & $(0.170)$ & $(0.306)$ & $(0.905)$ & $(0.698)$ \\
\hline Retail and wholesale & -0.165 & $-0.498 * * *$ & 0.636 & -1.848 & 0.708 \\
\hline trade & $(0.462)$ & $(0.177)$ & $(0.504)$ & $(1.654)$ & $(0.882)$ \\
\hline Government and & 0.082 & -0.325 & 0.304 & $10.446 * * *$ & 0.100 \\
\hline public administration & (1.393) & $(0.412)$ & $(1.252)$ & $(2.532)$ & $(2.418)$ \\
\hline \multirow[t]{2}{*}{ Construction } & 0.070 & 0.011 & -0.073 & 0.081 & $0.957 * * *$ \\
\hline & $(0.085)$ & $(0.076)$ & $(0.059)$ & $(0.218)$ & $(0.146)$ \\
\hline \multirow[t]{2}{*}{ Manufacturing } & $0.237 * *$ & $-0.098 * * *$ & -0.144 & -0.074 & $0.640 * * *$ \\
\hline & $(0.111)$ & $(0.033)$ & $(0.103)$ & $(0.224)$ & $(0.200)$ \\
\hline \multirow[t]{2}{*}{ Social services } & 0.171 & -0.049 & -0.119 & -0.700 & -0.080 \\
\hline & $(0.283)$ & $(0.091)$ & $(0.282)$ & $(0.610)$ & $(0.487)$ \\
\hline Transport and & 0.344 & -0.055 & -0.275 & -1.171 & 0.552 \\
\hline communications & $(0.229)$ & $(0.121)$ & $(0.225)$ & $(0.854)$ & $(0.547)$ \\
\hline Finance and business & $0.392 * * *$ & -0.043 & $-0.333^{*}$ & $2.462 * * *$ & 0.646 \\
\hline services & $(0.135)$ & $(0.093)$ & $(0.172)$ & $(0.670)$ & $(0.572)$ \\
\hline \multirow[t]{2}{*}{ Mining and utilities } & 0.221 & 0.025 & $-0.239 * *$ & 0.153 & -0.021 \\
\hline & $(0.134)$ & $(0.048)$ & $(0.116)$ & $(0.474)$ & $(0.257)$ \\
\hline$p$-value, test: $\beta 1=\beta 2=\ldots=\beta 10$ & 0.656 & 0.002 & 0.750 & 0.000 & 0.001 \\
\hline R-squared & 0.000 & 0.001 & 0.000 & 0.002 & 0.006 \\
\hline Observations & 331004 & 331004 & 331004 & 118384 & 174661 \\
\hline
\end{tabular}

Note: Individual level panel regressions in changes include year effects. Standard errors clustered on state or province. 
Table 9: Cross-country regressions of annualized changes in employment outcomes on overall growth and manufacturing-led export growth

\begin{tabular}{|c|c|c|c|c|c|}
\hline & $\begin{array}{c}\text { (I) } \\
\Delta \text { Employed }\end{array}$ & $\begin{array}{c}\text { (II) } \\
\Delta \text { Unemployed }\end{array}$ & $\begin{array}{c}\text { (III) } \\
\Delta \text { Out of the } \\
\text { labor force }\end{array}$ & $\begin{array}{c}\text { (IV) } \\
\Delta \text { Log(wages) }\end{array}$ & $\begin{array}{c}\text { (V) } \\
\Delta \text { Productivity }\end{array}$ \\
\hline \multirow[t]{2}{*}{ Log GDP growth, annualized } & -0.060 & $-0.064 * *$ & $0.124 * * *$ & $4.679 *$ & 0.409 \\
\hline & $(0.054)$ & $(0.026)$ & $(0.041)$ & $(2.633)$ & $(0.781)$ \\
\hline Log manufacturing exports & $0.028 * *$ & $-0.016 *$ & -0.011 & $-2.759 * *$ & -0.087 \\
\hline growth, annualized & $(0.013)$ & $(0.077)$ & $(0.012)$ & $(1.281)$ & $(0.557)$ \\
\hline R-squared & 0.033 & 0.077 & 0.062 & 0.075 & 0.001 \\
\hline Observations & 176 & 176 & 176 & 138 & 143 \\
\hline
\end{tabular}

Note: Standard errors clustered on country. 
Table 10: High vs. low productivity growth, interacted with labor mobility, within country

\begin{tabular}{|c|c|c|c|c|c|c|}
\hline & $\begin{array}{c}\text { (I) } \\
\Delta \text { Employed } \\
\text { Mexico }\end{array}$ & $\begin{array}{c}\text { (II) } \\
\Delta \text { Log(wages) } \\
\text { Mexico }\end{array}$ & $\begin{array}{c}\text { (III) } \\
\Delta \text { Employed } \\
\text { Indonesia }\end{array}$ & $\begin{array}{c}\text { (IV) } \\
\Delta \text { Log(wages) } \\
\text { Indonesia }\end{array}$ & $\begin{array}{c}\text { (V) } \\
\Delta \text { Employed } \\
\text { Brazil }\end{array}$ & $\begin{array}{c}\text { (VI) } \\
\Delta \\
\text { Log(wages } \\
\text { Brazil }\end{array}$ \\
\hline High productivity growth & $\begin{array}{l}3.738^{* * *} \\
(1.006)\end{array}$ & $\begin{array}{l}-8.381 * * \\
(3.935)\end{array}$ & $\begin{array}{c}-2.762 * * \\
(1.238)\end{array}$ & $\begin{array}{r}7.789 \\
(7.407)\end{array}$ & $\begin{array}{l}-0.058 \\
(0.044)\end{array}$ & $\begin{array}{r}0.323 \\
(0.176)\end{array}$ \\
\hline Low productivity growth & $\begin{array}{l}-2.913 * \\
(1.582)\end{array}$ & $\begin{array}{r}3.942 \\
(4.966)\end{array}$ & $\begin{array}{c}1.659 * * * \\
(0.401)\end{array}$ & $\begin{array}{l}-4.081 \\
(3.982)\end{array}$ & $\begin{array}{c}0.069 * \\
(0.031)\end{array}$ & $\begin{array}{l}-0.230 \\
(0.342)\end{array}$ \\
\hline $\begin{array}{l}\text { High productivity growth* } \\
\text { labor mobility }\end{array}$ & $\begin{array}{c}-12.185^{* * *} \\
(3.429)\end{array}$ & $\begin{array}{l}29.348^{* *} \\
(13.819)\end{array}$ & $\begin{array}{l}45.754 * * \\
(21.385)\end{array}$ & $\begin{array}{l}-108.786 \\
(139.243)\end{array}$ & $\begin{array}{r}0.354 \\
(0.279)\end{array}$ & $\begin{array}{l}-1.037 \\
(0.841)\end{array}$ \\
\hline $\begin{array}{l}\text { Low productivity growth* } \\
\text { labor mobility }\end{array}$ & $\begin{array}{r}10.544^{*} \\
(5.549)\end{array}$ & $\begin{array}{l}-13.572 \\
(17.612)\end{array}$ & $\begin{array}{c}-30.848 * * * \\
(8.156)\end{array}$ & $\begin{array}{c}75.011 \\
(72.964)\end{array}$ & $\begin{array}{l}-0.370 \\
(0.222)\end{array}$ & $\begin{array}{l}0.585 \\
0.653\end{array}$ \\
\hline $\begin{array}{l}\text { R-squared } \\
\text { Observations }\end{array}$ & $\begin{array}{r}0.001 \\
331004\end{array}$ & $\begin{array}{r}0.002 \\
118384\end{array}$ & $\begin{array}{r}0.020 \\
383493\end{array}$ & $\begin{array}{l}0.049 \\
45603\end{array}$ & $\begin{array}{r}0.000 \\
825304\end{array}$ & $\begin{array}{c}0.768 \\
42\end{array}$ \\
\hline
\end{tabular}

Note: Individual level panel regressions in changes include year effects. Standard errors clustered on state or province. 
Table 11: High vs. low productivity growth, interacted with measures of labor regulation, cross-country

\begin{tabular}{|c|c|c|c|c|c|}
\hline & $\begin{array}{c}\text { (I) } \\
\Delta \text { Employed }\end{array}$ & $\begin{array}{c}\text { (II) } \\
\Delta \text { Employed }\end{array}$ & $\begin{array}{c}\text { (III) } \\
\Delta \text { Employed }\end{array}$ & $\begin{array}{c}\text { (IV) } \\
\Delta \text { Employed }\end{array}$ & $\begin{array}{c}\text { (V) } \\
\Delta \text { Employed }\end{array}$ \\
\hline \multirow[t]{2}{*}{ High productivity growth } & 0.161 & $-0.752 *$ & $-0.640 * *$ & $-0.752 *$ & -0.693 \\
\hline & $(0.290)$ & $(0.423)$ & $(0.283)$ & $(0.423)$ & $(0.440)$ \\
\hline \multirow[t]{2}{*}{ Low productivity growth } & -0.204 & 0.338 & $0.321 *$ & 0.338 & 0.217 \\
\hline & $(0.269)$ & $(0.321)$ & $(0.192)$ & $(0.321)$ & $(0.331)$ \\
\hline High productivity growth* & -0.006 & & & & -0.037 \\
\hline hiring flexibility & $(0.004)$ & & & & $(0.064)$ \\
\hline Low productivity growth* & 0.005 & & & & -0.098 \\
\hline hiring flexibility & $(0.004)$ & & & & $(0.090)$ \\
\hline High productivity growth* & & 0.008 & & & -0.026 \\
\hline employment conditions & & $(0.006)$ & & & $(0.064)$ \\
\hline Low productivity growth* & & -0.004 & & & -0.107 \\
\hline employment conditions & & $(0.005)$ & & & (0.089) \\
\hline High productivity growth* & & & $0.011^{*}$ & & -0.018 \\
\hline firing flexibility & & & $(0.006)$ & & $(0.060)$ \\
\hline Low productivity growth* & & & -0.007 & & -0.109 \\
\hline firing flexibility & & & $(0.005)$ & & $(0.089)$ \\
\hline High productivity growth* & & & & 0.008 & 0.094 \\
\hline employment laws & & & & $(0.006)$ & $(0.191)$ \\
\hline Low productivity growth* & & & & -0.004 & 0.309 \\
\hline employment laws & & & & $(0.005)$ & $(0.271)$ \\
\hline R-squared & 0.047 & 0.051 & 0.057 & 0.051 & 0.113 \\
\hline Observations & 175 & 175 & 175 & 175 & 175 \\
\hline
\end{tabular}

Note: Standard errors clustered on country. 
Table 12: Longer-term growth and employment outcomes, 3 sectors

\begin{tabular}{|c|c|c|c|c|c|}
\hline & $\begin{array}{c}\text { (I) } \\
\Delta \text { Employed }\end{array}$ & $\begin{array}{c}\text { (II) } \\
\Delta \text { Unemployed }\end{array}$ & $\begin{array}{c}\text { (III) } \\
\Delta \text { Out of the } \\
\text { labor force }\end{array}$ & $\begin{array}{c}\text { (IV) } \\
\Delta \log (\text { income) }\end{array}$ & $\begin{array}{c}\text { (V) } \\
\Delta \text { Productivity }\end{array}$ \\
\hline \multicolumn{6}{|l|}{ Brazil, 1960-2000 } \\
\hline \multirow[t]{2}{*}{ Agriculture growth } & 0.004 & -0.008 & 0.004 & 0.109 & 0.078 \\
\hline & $(0.018)$ & $(0.006)$ & $(0.014)$ & $(0.066)$ & $(0.050)$ \\
\hline \multirow[t]{2}{*}{ Services growth } & -0.003 & $-0.011^{*}$ & 0.013 & 0.100 & $0.128 * *$ \\
\hline & $(0.017)$ & $(0.006)$ & $(0.014)$ & $(0.065)$ & $(0.055)$ \\
\hline \multirow[t]{2}{*}{ Industry growth } & 0.005 & $-0.013^{*}$ & 0.007 & $0.111^{*}$ & $0.128 * * *$ \\
\hline & $(0.017)$ & $(0.006)$ & $(0.013)$ & $(0.062)$ & $(0.043)$ \\
\hline$p$-value, test: $\beta 1=\beta 2=\beta 3$ & 0.019 & 0.000 & 0.014 & 0.394 & 0.001 \\
\hline R-squared & 0.232 & 0.052 & 0.252 & 0.817 & 0.498 \\
\hline Observations & 4176163 & 4176163 & 4176163 & 2314738 & 2853088 \\
\hline \multicolumn{6}{|l|}{ Indonesia, 1971-2010 } \\
\hline \multirow[t]{2}{*}{ Agriculture growth } & $0.019 * * *$ & $-0.001 * * *$ & $-0.019 * * *$ & -- & $0.651 * * *$ \\
\hline & $(0.000)$ & $(0.000)$ & $(0.001)$ & & $(0.184)$ \\
\hline \multirow[t]{2}{*}{ Services growth } & $0.016 * * *$ & $0.001 * * *$ & $-0.017 * * *$ & -- & $0.730 * * *$ \\
\hline & $(0.001)$ & $(0.000)$ & $(0.001)$ & & $(0.172)$ \\
\hline \multirow[t]{2}{*}{ Industry growth } & $0.014 * * *$ & 0.000 & $-0.014 * * *$ & -- & $0.692 * * *$ \\
\hline & $(0.001)$ & $(0.000)$ & $(0.000)$ & & $(0.181)$ \\
\hline$p$-value, test: $\beta 1=\beta 2=\beta 3$ & 0.000 & 0.000 & 0.000 & & 0.000 \\
\hline R-squared & 0.244 & 0.004 & 0.244 & & 0.999 \\
\hline Observations & 1538919 & 1538919 & 1538919 & & 3421263 \\
\hline \multicolumn{6}{|l|}{ Mexico, $1990-2010$} \\
\hline \multirow[t]{2}{*}{ Agriculture growth } & 0.031 & $0.003 * *$ & $-0.048 * *$ & $-1.466 * * *$ & $1.009 * * *$ \\
\hline & (0.019) & $(0.002)$ & $(0.024)$ & $(0.494)$ & $(0.115)$ \\
\hline \multirow[t]{2}{*}{ Services growth } & 0.022 & $0.003^{*}$ & -0.040 & $-1.231 * * *$ & $0.952 * * *$ \\
\hline & $(0.017)$ & $(0.001)$ & $(0.023)$ & $(0.445)$ & $(0.101)$ \\
\hline \multirow[t]{2}{*}{ Industry growth } & 0.021 & 0.001 & $-0.038^{*}$ & $-1.102 * * *$ & $0.923 * * *$ \\
\hline & $(0.016)$ & $(0.001)$ & $(0.020)$ & $(0.389)$ & $(0.96)$ \\
\hline$p$-value, test: $\beta 1=\beta 2=\beta 3$ & 0.065 & 0.001 & 0.062 & 0.028 & 0.005 \\
\hline R-squared & 0.170 & 0.004 & 0.182 & 0.209 & 0.609 \\
\hline Observations & 5467781 & 5467781 & 5467781 & 3153527 & 1743735 \\
\hline
\end{tabular}

Note: Regressions include state or province and year effects. Standard errors clustered on state or province. 
Appendix Table 1: Countries included in cross-country sample

\begin{tabular}{|c|c|}
\hline Country & Spells \\
\hline Albania & 1996-2002, 2002-2005 \\
\hline Argentina & 1994-2001, 2001-2006 \\
\hline Armenia & 1999-2003 \\
\hline Austria & 2005-2006, 2006-2007, 2007-2008 \\
\hline Azerbaijan & $1995-2002$ \\
\hline Bangladesh & 1991-2000, 2000-2005, 2005-2010 \\
\hline Belarus & $1995-2002,2002-2005$ \\
\hline Belgium & 2005-2006, 2006-2007, 2007-2008 \\
\hline Bhutan & $2003-2007$ \\
\hline Bolivia & 1993-1996, 1996-2002, 2002-2005 \\
\hline Bosnia and Herzegovina & $2001-2004$ \\
\hline Brazil & 1987-1995, 1995-1999, 1999-2005, 2005-2008 \\
\hline Bulgaria & 1995-2001, 2001-2003, 2003-2008 \\
\hline Burkina Faso & $1994-2003$ \\
\hline Cambodia & $1997-2004$ \\
\hline Cameroon & 1996-2001, 2001-2007 \\
\hline Canada & 1981-1991, 1991-2001 \\
\hline Chile & $\begin{array}{c}1990-1992,1992-1994,1994-1996,1996-1998,1998- \\
\text { 2000, 2000-2003, 2003-2006, 2006-2009 }\end{array}$ \\
\hline Colombia & $1995-2000$ \\
\hline Costa Rica & 1995-2001, 2001-2006 \\
\hline Cyprus & 2005-2006, 2006-2007, 2007-2008 \\
\hline Czech Republic & 2005-2006, 2006-2007, 2007-2008 \\
\hline Denmark & 2005-2006, 2006-2007 \\
\hline Djibouti & $1996-2002$ \\
\hline Dominican Republic & $1997-2004$ \\
\hline Ecuador & $1995-2004$ \\
\hline El Salvador & 1995-2002, 2002-2005 \\
\hline Estonia & 2004-2005, 2005-2006, 2006-2007, 2007-2008 \\
\hline Ethiopia & $1995-2000,2000-2004$ \\
\hline Finland & 2005-2006, 2006-2007 \\
\hline France & 2005-2006, 2006-2007 \\
\hline Ghana & 1991-1998, 1998-2005 \\
\hline Greece & 2005-2006, 2006-2007, 2007-2008 \\
\hline Guatemala & 1989-2002, 2002-2006 \\
\hline Honduras & $1995-2003$ \\
\hline Hungary & $\begin{array}{c}1998-2002,2002-2004,2004-2005,2005-2006,2006- \\
2007\end{array}$ \\
\hline Iceland & 2005-2006, 2006-2007 \\
\hline India & $\begin{array}{c}1983-1987,1987-1993,1993-1999,1999-2004,2004- \\
2007,2007-2009\end{array}$ \\
\hline Indonesia & 1993-1997, 1997-2002 \\
\hline Ireland & 2005-2006, 2006-2007, 2007-2008 \\
\hline Italy & 2005-2006, 2006-2007, 2007-2008 \\
\hline Jamaica & $1996-2002$ \\
\hline Kazakhstan & $1996-2002,2002-2003$ \\
\hline Kenya & 1997-2005 \\
\hline
\end{tabular}




\begin{tabular}{|c|c|}
\hline Latvia & $2004-2005,2005-2006,2006-2007,2007-2008$ \\
\hline Lithuania & $\begin{array}{c}2000-2004,2004-2005,2005-2006,2006-2007,2007- \\
2008\end{array}$ \\
\hline Luxembourg & 2005-2006, 2006-2007, 2007-2008 \\
\hline Madagascar & 1993-2001 \\
\hline Malawi & $1997-2005$ \\
\hline Mali & $1994-2003$ \\
\hline Mauritius & 1999-2003, 2003-2008 \\
\hline Mexico & $\begin{array}{c}2000-2002,2002-2004,2004-2005,2005-2006,2006- \\
2008\end{array}$ \\
\hline Montenegro & $2002-2006$ \\
\hline Morocco & 1991-1998 \\
\hline Mozambique & $1996-2003$ \\
\hline Nepal & $1995-2003,2003-2008$ \\
\hline Netherlands & 2005-2006, 2006-2007 \\
\hline Nicaragua & 1993-2001, 2001-2005 \\
\hline Niger & 1995-2002 \\
\hline Nigeria & 1993-2003 \\
\hline Norway & 2005-2006, 2006-2007 \\
\hline Pakistan & $\begin{array}{c}1991-1992,1992-1999,1999-2001,2001-2005,2005- \\
2007,2007-2008\end{array}$ \\
\hline Panama & 1991-1995, 1995-2003 \\
\hline Paraguay & 1995-2001, 2001-2006 \\
\hline Peru & 1994-2002 \\
\hline Philippines & 1997-1998, 1998-2002, 2002-2006 \\
\hline Poland & $\begin{array}{c}1998-2004,2004-2005,2005-2006,2006-2007,2007- \\
2008\end{array}$ \\
\hline Portugal & 2005-2006, 2006-2007, 2007-2008 \\
\hline Romania & 1994-2002, 2002-2006, 2006-2008 \\
\hline Rwanda & $1997-2005$ \\
\hline Slovenia & $2004-2005,2005-2006,2006-2007,2007-2008$ \\
\hline Spain & 2005-2006, 2006-2007, 2007-2008 \\
\hline Sri Lanka & $\begin{array}{c}1995-2000,2000-2002,2002-2004,2004-2006,2006- \\
2008\end{array}$ \\
\hline Swaziland & $1995-2000$ \\
\hline Sweden & 2005-2006, 2006-2007, 2007-2008 \\
\hline Thailand & $\begin{array}{c}1990-1994,1994-2000,2000-2002,2002-2006,2006- \\
2009\end{array}$ \\
\hline Tunisia & 1997-2000, 2000-2001 \\
\hline Turkey & $2000-2005$ \\
\hline Uganda & $1992-2002,2002-2005$ \\
\hline Ukraine & $1999-2003,2003-2005$ \\
\hline Uruguay & 1995-2003, 2003-2006 \\
\hline
\end{tabular}


Appendix Table 2: GDP and differential impacts of high and low productivity growth across countries

\begin{tabular}{|c|c|c|c|c|c|}
\hline & $\begin{array}{c}\text { (I) } \\
\Delta \text { Employed }\end{array}$ & $\begin{array}{c}\text { (II) } \\
\Delta \text { Unemployed }\end{array}$ & $\begin{array}{c}\text { (III) } \\
\Delta \text { Out of the } \\
\text { labor force }\end{array}$ & $\begin{array}{c}\text { (IV) } \\
\Delta \text { Log(wages) }\end{array}$ & $\begin{array}{c}\text { (V) } \\
\Delta \text { Productivity }\end{array}$ \\
\hline \multicolumn{6}{|l|}{ Interacted with $\log (G D P$ in 2000) } \\
\hline \multirow[t]{2}{*}{ High productivity growth } & -0.521 & 0.163 & 0.358 & -18.049 & $16.502^{* *}$ \\
\hline & $(0.436)$ & $(0.229)$ & $(0.465)$ & $(19.877)$ & (6.495) \\
\hline \multirow[t]{2}{*}{ Low productivity growth } & -0.251 & 0.075 & 0.177 & 19.818 & -5.920 \\
\hline & $(0.305)$ & $(0.227)$ & $(0.310)$ & $(15.144)$ & $(7.632)$ \\
\hline High productivity growth * & 0.044 & -0.014 & -0.030 & 3.017 & $-2.177^{* *}$ \\
\hline $\log (G D P$ in 2000) & $(0.059)$ & $(0.030)$ & $(0.061)$ & (3.111) & $(0.955)$ \\
\hline Low productivity growth * & 0.060 & -0.041 & -0.019 & -2.700 & 0.660 \\
\hline $\log (G D P$ in 2000$)$ & $(0.041)$ & $(0.034)$ & $(0.038)$ & $(2.325)$ & $(1.240)$ \\
\hline R-squared & 0.088 & 0.087 & 0.065 & 0.015 & 0.010 \\
\hline Observations & 193 & 193 & 193 & 151 & 151 \\
\hline \multicolumn{6}{|l|}{ By income categories } \\
\hline High productivity growth * & $-0.242 *$ & 0.012 & 0.230 & -4.219 & $4.455^{* * *}$ \\
\hline Low income country & $(0.129)$ & $(0.119)$ & $(0.145)$ & $(3.845)$ & $(1.491)$ \\
\hline Low productivity growth * & 0.089 & $-0.167^{*}$ & 0.078 & 7.644* & $-3.958 * * *$ \\
\hline Low income country & (0.119) & $(0.085)$ & $(0.134)$ & $(4.212)$ & $(1.475)$ \\
\hline High productivity growth * & $-0.400 * *$ & $0.110 * *$ & 0.290 & 15.721 & -9.338 \\
\hline Lower middle income country & $(0.166)$ & $(0.054)$ & $(0.188)$ & $(20.489)$ & $(6.732)$ \\
\hline Low productivity growth * & $0.403 * * *$ & $-0.311 * * *$ & -0.092 & -26.312 & 5.964 \\
\hline Lower middle income country & $(0.122)$ & $(0.095)$ & $(0.188)$ & $(17.930)$ & $(5.662)$ \\
\hline High productivity growth $*$ & $-0.374 *$ & 0.232 & 0.142 & 4.428 & 2.981 \\
\hline Upper middle income country & $(0.224)$ & $(0.245)$ & $(0.140)$ & $(3.057)$ & $(6.333)$ \\
\hline Low productivity growth * & $0.456 * *$ & -0.567 & 0.111 & 4.890 & $-9,121$ \\
\hline Upper middle income country & $(0.227)$ & $(0.352)$ & $(0.261)$ & $(5.858)$ & $(11.110)$ \\
\hline High productivity growth * & 0.127 & 0.140 & -0.267 & 3.253 & -7.210 \\
\hline High income country & $(0.255)$ & $(0.113)$ & $(0.217)$ & (3.201) & $(4.896)$ \\
\hline Low productivity growth * & -0.120 & $-0.437 * * *$ & $0.556 * *$ & 6.984 & 0.035 \\
\hline High income country & $(0.285)$ & $(0.117)$ & $(0.247)$ & $(5.264)$ & (3.773) \\
\hline R-squared & 0.067 & 0.085 & 0.047 & 0.149 & 0.040 \\
\hline Observations & 193 & 193 & 193 & 151 & 151 \\
\hline
\end{tabular}

Note: Standard errors clustered on country. 